\title{
Diphenyl ether derivatives occupy the expanded binding site of cyclohexanedione compounds at the colchicine site in tubulin by movement of the $\alpha \mathrm{T} 5$ loop.
}

\author{
Oskia Bueno, ${ }^{1}$ Marta Gargantilla ${ }^{1}$, Juan Estévez-Gallego ${ }^{2}$, Solange \\ Martins $^{3}$,J. Fernando Díaz ${ }^{2}$, María-José Camarasa ${ }^{1}$, Sandra Liekens ${ }^{3}$, \\ María-Jesús Pérez-Pérez ${ }^{1}$ and Eva-María Priego ${ }^{1, *}$
}

${ }^{1}$ Instituto de Química Médica (IQM, CSIC), Juan de la Cierva 3, 28006 Madrid, Spain;

2 Centro de Investigaciones Biológicas (CSIC), Ramiro de Maeztu 9, 28040 Madrid, Spain;

3 Rega Institute for Medical Research, KU Leuven, Herestraat 49, B-3000 Leuven, Belgium;

\footnotetext{
* Corresponding author: Dr. Eva-Maria Priego Crespo Instituto de Química Médica (CSIC)

c/ Juan de la Cierva 3

E-28006 Madrid (Spain)

Phone number: +34 915690040

Fax number: +34 915644853

e-mail: empriego@iqm.csic.es
} 


\begin{abstract}
Microtubule targeting agents represent a very active arena in the development of anticancer agents. In particular, compounds binding at the colchicine site in tubulin are being deeply studied, and the structural information recently available on this binding site allows structuredirected design of new ligands. Structural comparison of our recently reported high resolution X-Ray structure of the cyclohexanedione derivative TUB075 bound to tubulin and the tubulinDAMA-colchicine complex has revealed a conformational change in the $\alpha \mathrm{T} 5$ loop. By a gridbased computational analysis of the tubulin-DAMA-colchicine binding site, we have identified a new favorable binding area in the colchicine-site that was unexplored by our lead TUB075. Thus, based on a structure-guided design, new cyclohexanedione derivatives have been synthesized and tested for tubulin binding and in cellular assays. As a result, we have identified diphenyl ether derivatives with $\mathrm{IC}_{50}$ values around 10-40 $\mathrm{nM}$ against three different tumor cell lines and affinity constants for tubulin similar to that of colchicine around $10^{7} \mathrm{M}^{-1}$. As expected, they halted the cell cycle progression at $\mathrm{G} 2 / \mathrm{M}$ phase at concentrations as low as $0.08 \mu \mathrm{M}$.
\end{abstract}

Keywords: colchicine domain, structure-based design, affinity maps, diphenyl ethers 


\section{Introduction}

Microtubules are highly dynamic polymers composed of $\alpha \beta$-tubulin heterodimers. These key components of the cytoskeleton of eukaryotic cells are involved in pivotal biological functions such as intracellular migration and transport, cell signalling, cell shape maintenance, cell motility and mitosis [1]. Their crucial role in cell division has made tubulin and microtubules important targets for several conditions, especially for cancer, and therefore antitubulin compounds represent the most successful class of antimitotic agents in cancer chemotherapy [2]. To date, several chemical classes of microtubule targeting agents (MTAs) are known, both from natural sources or synthetic derivatives $[3,4]$.

At the cellular level, and according to their mechanism of action, MTAs can be divided as microtubule-stabilizing agents [5], i.e., placlitaxel (1) from the taxoid family, epothilone A (2) and laulimalilde (3) or as destabilizing agents like the vinca alkaloids such as vinblastine (4), colchicine (5) or combretastatins $(\mathbf{6}, \mathbf{7})$, among others (Figure 1) [3].

A

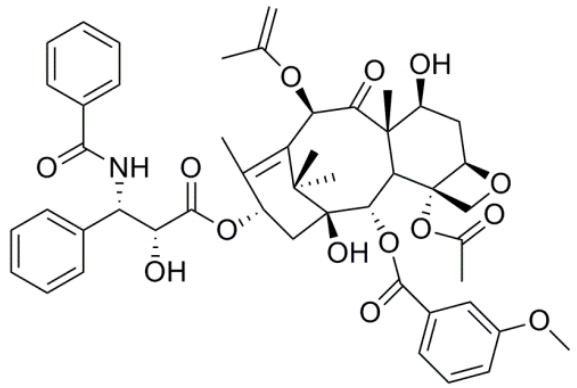

1 Placlitaxel (taxoid family)

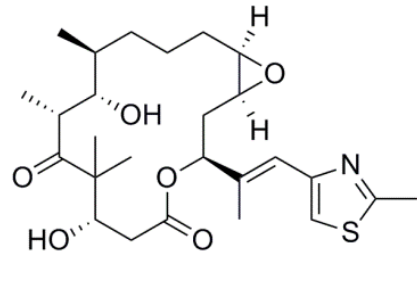

2 Epotilone A

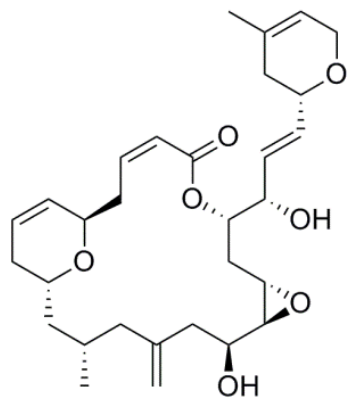

3 Laulimalide

B

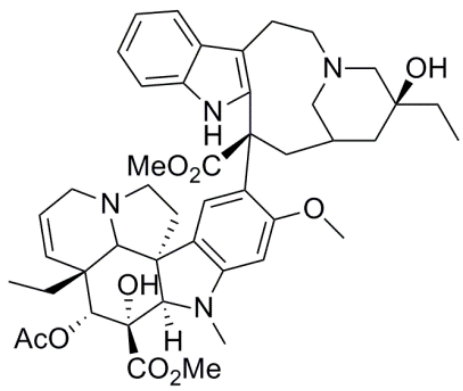

4 Vinblastine (vinca alcaloids)

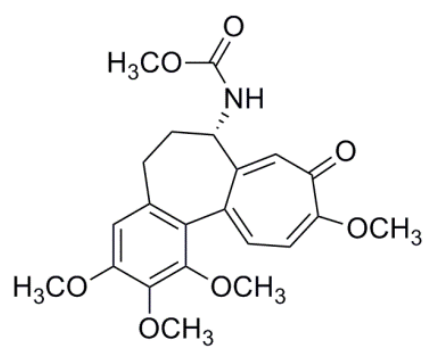

5 Colchicine<smiles>COc1ccc(/C=C\c2cc(OC)c(OC)c(OC)c2)cc1O</smiles>

$6 \mathrm{R}=\mathrm{H}$ Combretastatin A-4 (CA-4) $7 \mathrm{R}=\mathrm{PO}(\mathrm{ONa}) 2 \mathrm{CA}-4 \mathrm{P}$

Figure 1. Chemical structures of selected microtubule-stabilizing (A) and microtubule-destabilizing (B) agents.

At the molecular level, MTAs bind to $\alpha \beta$-tubulin heterodimers at six different binding sites that are referred to as the taxane, colchicine, vinca, maytansine, laulimalide/peloruside and pironetin 
sites, all of which have been structurally characterized by high resolution X-ray crystallography and cryo-electron microscopy [6].

As recently reviewed [7], the mechanism of action of MTAs goes far beyond than acting as antimitotic agents. Since microtubule structure and function are crucial for cell motility and shape, compounds affecting microtubules dynamics may lead to antimetastatic and antiangiogenic effects $[8,9]$. Tubulin destabilization has also been linked to vascular disruption so that morphological changes in the vascular endothelial cells increase vascular permeability leading to blood flow occlusion. This is particularly relevant for tumor vessels because of their significant differences with physiological vessels (i.e increased vascular permeability) [10]. Thus, treatment with vascular disrupting agents (VDAs) has been proposed as an interesting antitumor approach leading to vascular shutdown and tumor necrosis, although the outer rim of the tumor remains unaffected, which support the use of VDAs combined with other anticancer treatments [11]. Among VDAs, destabilizing tubulin-colchicine-site binders have been extensively studied $[12,13]$.

The colchicine site is a hydrophobic pocket located near the intra-dimer interface between the $\alpha$ and $\beta$ tubulin subunits [14]. Based on the structural information available, two distinct binding modes of colchicine-site ligands have been characterized [15], with compounds that bind deeper in the $\beta$ subunit such as TN-16 (8), and compounds that bind closer to the interface between $\alpha$ and $\beta$ subunits of a tubulin dimer, the prototype being DAMA-colchicine (9) (Figure2A). We have recently reported the high resolution X-Ray structure of the cyclohexanedione derivative TUB075 (10, Figure 2A) bound to $\alpha \beta$-tubulin, compound that binds mostly at the $\beta$-subunit, similar to TN-16 [16]. Superposition of the crystal structures of tubulin-DAMA-colchicine and tubulin-TUB075 complexes revealed a significant conformational change of the $\alpha$-T5 loop (Figure 2B). This loop closed the TUB075 binding site in the tubulin-TUB075 complex while it was flipped out in the DAMA-colchicine structure. Based on this loop movement, it could be argued that DAMA-colchicine makes uses of binding/affinity areas of the binding domain that are not accessible for TUB075. Therefore, we have dissected the binding mode of DAMAcolchicine with different probes, using the computational tool cGRILL [17]. By unravelling new potential affinity areas with cGRILL, structure-guided design of TUB075 based derivatives has been carried out leading to the synthesis of new cyclohexanedione derivatives with a distal diphenyl ether moiety. In addition, the tubulin binding and the antiproliferative evaluation of the new compounds have been accomplished. 
A
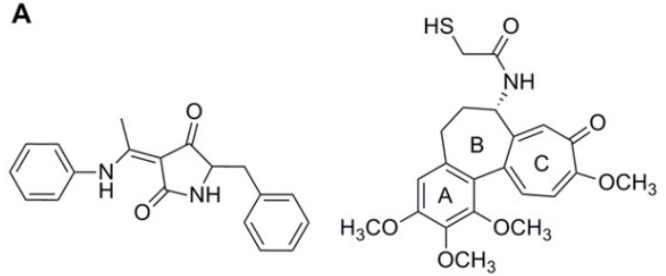

$8 \mathrm{TN}-16$

9 DAMA-Colchicine

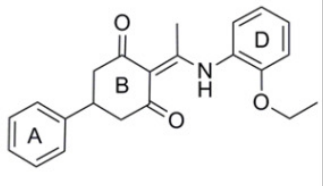

10 TUB075

B

Tubulin-TUB075 complex

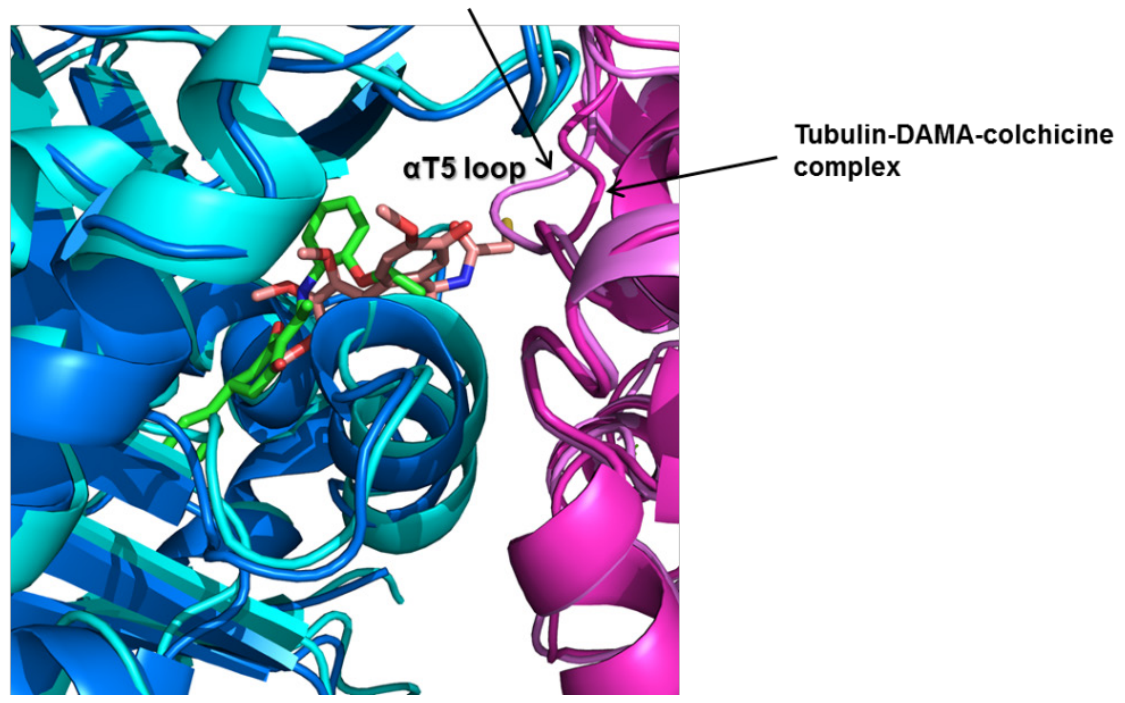

Figure 2. (A) Chemical structures of TN-16, DAMA-colchicine and TUB075. (B) Movement of the $\alpha$-T5 loop: Superposition of tubulin-DAMA-colchicine complex ( $\alpha$-tubulin in magenta, $\beta$-tubulin in blue marine and DAMA-colchicine in orange) with TUB075-tubulin complex ( $\alpha$-tubulin in light pink, $\beta$ tubulin in cyan and TUB075 in green)

\section{Results and Discussion}

2.1 Affinity maps of the DAMA-colchicine-tubulin complex for the design of new ligands.

To identify new favourable binding areas unexplored by TUB075 at the colchicine domain, the corresponding affinity maps on the tubulin-DAMA-colchicine complex (PDB ID: 1sa0)[14] were generated by means of the computational tool cGRILL and the lipophilic probe $(\mathrm{CH} 3+)$ $[17,18]$. As shown in Figure 3A, three well-defined affinity areas encircle DAMA-colchicine: area 1 , located inside the $\beta$-subunit; area 2 , covering the lower part of the trimethoxyphenyl ring of DAMA-colchicine (ring A); and area 3, where the tropone ring of DAMA-colchicine (ring C) is located. When TUB075 was superimposed onto this affinity maps, it became clear that areas 1 and 2 were already occupied by rings A, B and D of TUB75, whereas area 3 was scarcely explored by TUB075 although the ethoxy group seemed to point towards it. Given the shape and the lipophilic character of this unexplored area, we reasoned that, keeping the oxygen atom as bridge, the incorporation of an additional aromatic ring (named ring $\mathrm{E}$ ) linked to ring $\mathrm{D}$, could fulfil this affinity region, thus resulting in new diphenyl ether derivatives (Figure 3B). 


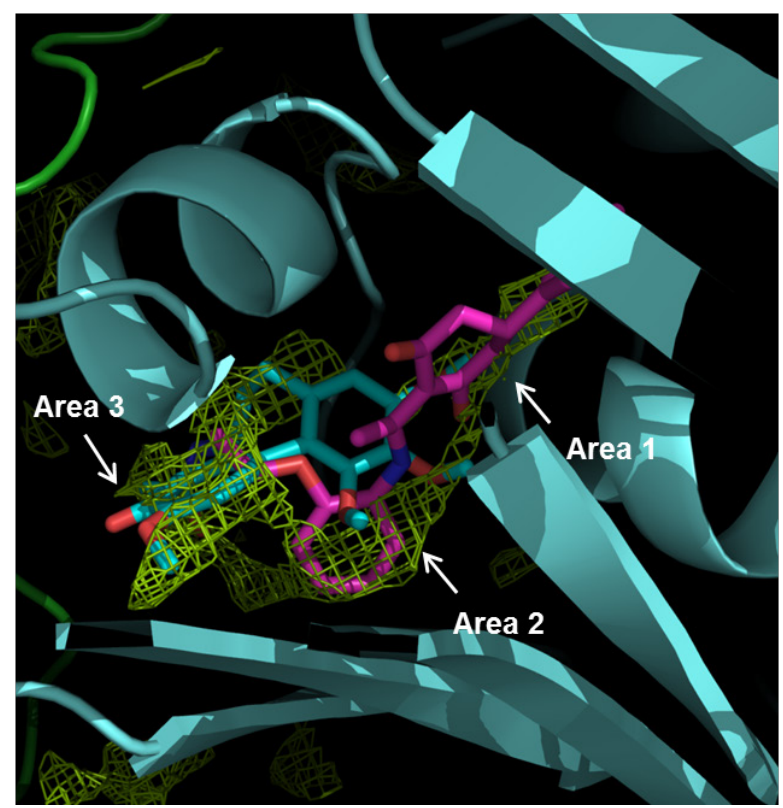

B

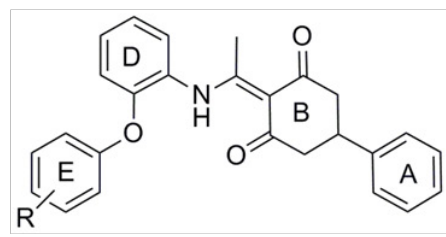

Figure 3. (A) Affinity maps generated with the lipophilic probe $\mathrm{CH} 3+$ (green grid) onto tubulin-DAMAcolchicine (cyan sticks) complex and its superposition with TUB075 (magenta sticks). (B) General structure of the new diphenyl ether derivatives

\subsection{Chemistry.}

The synthesis of the required 2-phenoxyanilines (14a-j) was carried out in a two-step process involving the nucleophilic aromatic substitution $\left(S_{N} A r\right)$ of 1-fluoro-2-nitrobenzene (11) with differently functionalized phenols at positions 3 and/or 4 , followed by reduction of the nitro derivatives (Scheme 1). Thus, 2-nitrodiphenyl ethers (12a-e) were prepared via a modified described procedure [19]. Reaction of 1-fluoro-2-nitrobenzene (11) with 3-fluoro (12a), 4chloro (12b), 3-methoxy (12c), 4-methoxy (12d) and 3,4-dimethoxy (12e) phenols in the presence of $\mathrm{Cs}_{2} \mathrm{CO}_{3}$ in acetonitrile at $80{ }^{\circ} \mathrm{C}$ afforded the corresponding nitro derivatives (13a-e) in excellent yields (88-99\%). Under the same conditions, the NH-Boc protected phenols (12fh)[20-22] and 4-hydroxyacetophenone (12i) reacted with 11 to yield the corresponding nitro derivatives 13f-i. Finally, catalytic hydrogenation of the halogenated compounds 13a-b in the presence of $\mathrm{Pt} / \mathrm{S}$ or in the presence of $\mathrm{Pd} / \mathrm{C}$ for the rest of the compounds (13c-i), yielded the corresponding 2-phenoxyanilines 14a-i. Aniline 14i was obtained in $42 \%$ yield together with compound $\mathbf{1 4} \mathbf{j}$ by partial reduction of the carbonyl group. 
<smiles>O=[N+]([O-])c1ccccc1F</smiles>

11<smiles>[R2]c1ccc(O)cc1[R]</smiles>

12a-i<smiles>[R]c1ccc(Oc2ccccc2[N+](=O)[O-])cc1[R]</smiles>

13a-i b or $c$<smiles>[R]c1ccc(Oc2ccccc2N)cc1[R]</smiles>

$14 a-j$

$$
\begin{aligned}
& \text { a } \mathrm{R}_{1}=\mathrm{F} ; \mathrm{R}_{2}=\mathrm{H} \\
& \text { b } \mathrm{R}_{1}=\mathrm{H} ; \mathrm{R}_{2}=\mathrm{Cl} \\
& \text { c } \mathrm{R}_{1}=\mathrm{OCH}_{3} ; \mathrm{R}_{2}=\mathrm{H} \\
& \text { d } \mathrm{R}_{1}=\mathrm{H} ; \mathrm{R}_{2}=\mathrm{OCH}_{3} \\
& \text { e } \mathrm{R}_{1}=\mathrm{R}_{2}=\mathrm{OCH}_{3} \\
& \text { f } \mathrm{R}_{1}=\mathrm{NHBoc} ; \mathrm{R}_{2}=\mathrm{H} \\
& \text { g } \mathrm{R}_{1}=\mathrm{H} ; \mathrm{R}_{2}=\mathrm{NHBOC} \\
& \text { h } \mathrm{R}_{1}=\mathrm{OMe} ; \mathrm{R}_{2}=\mathrm{NHBoc} \\
& \text { i } \mathrm{R}_{1}=\mathrm{H}, \mathrm{R}_{2}=\mathrm{COCH}_{3} \\
& \text { j } \mathrm{R}_{1}=\mathrm{H}, \mathrm{R}_{2}=\mathrm{CHOHCH}_{3}
\end{aligned}
$$

Scheme 1. Reagents and conditions: (a) $\mathrm{Cs}_{2} \mathrm{CO}_{3}, \mathrm{CH}_{3} \mathrm{CN}, 80{ }^{\circ} \mathrm{C}, 2-5 \mathrm{~h}, 88-99 \%$ yields; (b) for 13a,b: $\mathrm{H}_{2}$, $\mathrm{Pt} / \mathrm{S}$ 5\%, AcOEt, 30 psi, rt, 2 h, 74-84\% yields; (c) for 13e-i: $\mathrm{H}_{2}$, Pd/C 10\%, AcOEt, 30 psi, rt, 1-4 h, $42-$ $99 \%$ yields.

As shown in Scheme 2, reaction of 2-acetyl-5-phenylcyclohexane-1,3-dione (15) [23] with the synthesized anilines $\mathbf{1 4 a - j}$ in toluene at $110{ }^{\circ} \mathrm{C}$ in the presence of $4 \AA$ molecular sieves [24] led to the final compounds 16a-j in moderate to good yields. For comparative purposes, the unsubstituted derivative at ring E (16k) was also synthesized from the commercially available 2-phenoxyaniline (14k). Finally, treatment of $N$-Boc derivatives 16f-h with TFA yielded the free amino cyclohexanediones 161-n.<smiles>[R]c1ccc(Oc2ccccc2N)cc1[R]</smiles>

14a-k

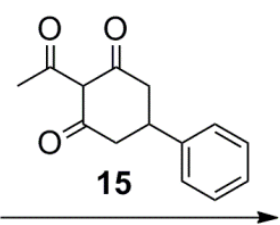

a<smiles>[R]c1ccc(Oc2ccccc2NC(C)=C2C(=O)CC(c3ccccc3)CC2=O)cc1[R]</smiles>

16a-n

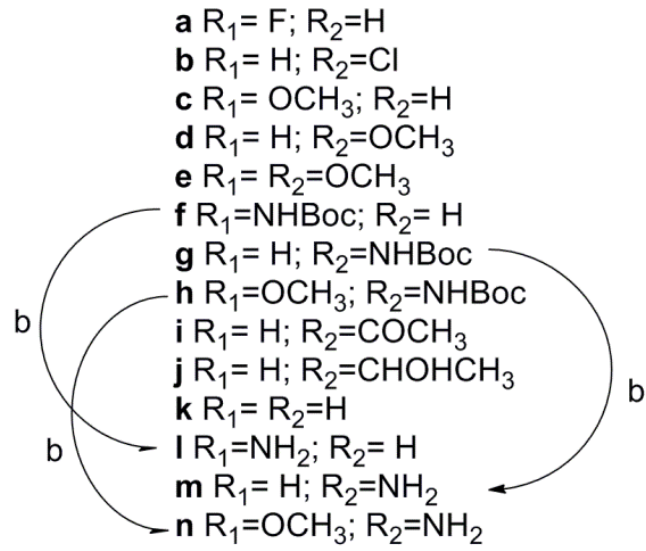


Scheme 2. Reagents and conditions: (a) Toluene, molecular sieves $4 \AA$, pressure tube, $110{ }^{\circ} \mathrm{C}, 16 \mathrm{~h}, 28$ 99\% yields; (b) TFA, $\mathrm{CH}_{2} \mathrm{Cl}_{2}, \mathrm{rt}, 20$ min- 1 h, 88-99\% yields.

\subsection{Antiproliferative activity}

The synthesized diphenyl ether derivatives were evaluated for their anti-proliferative activity in three different cancer cell lines [mouse leukemia (L1210), human lymphoblastic leukemia (CEM) and human cervical carcinoma (HeLa) cells] and one endothelial cell line [human microvascular endothelial cells (HMEC-1)]. Data are collected in Table 1 and expressed as $\mathrm{IC}_{50}$ (50\% inhibitory concentration) representing the concentration at which the compounds reduce cell proliferation by 50\%. Colchicine (5) and CA-4P (7) are included as reference compounds while data from our previous hit TUB075 (10) is included for comparative purposes [16].

The data collected in Table 1 revealed that the introduction of an extra aromatic ring (ring E) in the structure of TUB075 led to highly potent antiproliferative compounds with $\mathrm{IC}_{50}$ in the submicromolar range in all the cells lines tested. Thus, compound $\mathbf{1 6} \mathbf{k}$ with an unsubstituted phenyl ring provides $\mathrm{IC}_{50}$ values similar or slightly better than those of the reference compound TUB075. Incorporation of halogens at this phenyl ring, either a fluor at position 3 (16a) or a chlorine at position $4(\mathbf{1 6 b})$ did not improve the antiproliferative activity. On the other hand, introduction of a methoxy group at position 3, 4 or both (derivatives 16c, 16d and 16e, respectively) led to an improvement in the antiproliferative activities with $\mathrm{IC}_{50}$ values ranging from $0.04-0.16 \mu \mathrm{M}$, being the 3-OMe derivative 16c the most potent among them. Interestingly, compounds with amino groups in positions 3 or 4 of ring E, (161 and $\mathbf{1 6 m}$, respectively) also provided very interesting antiproliferative activities, with $\mathrm{IC}_{50}$ values ranging between 0.037 $0.082 \mu \mathrm{M}$. Finally, the double substituted compound 16n, with a methoxy group at 3 and an amino group at 4 , provided excellent antiproliferative activity against all the cell lines tested with $\mathrm{IC}_{50}$ values between 0.012 and $0.033 \mu \mathrm{M}$. 
Table 1. Anti-proliferative activity of the diphenylether derivatives (16a-n) in endothelial and tumor cell lines.

\begin{tabular}{|c|c|c|c|c|}
\hline & Tumor cells & & & Endothelial cells \\
\hline & $\mathrm{IC}_{50}(\mu \mathrm{M})^{\mathrm{a}}$ & & & $\mathrm{IC}_{50}(\mu \mathrm{M})^{\mathrm{a}}$ \\
\hline Comp. & L1210 & CEM & HeLa & HMEC-1 \\
\hline TUB075 (10) & $0.19 \pm 0.05$ & $0.19 \pm 0.01$ & $0.18 \pm 0.0$ & $0.10 \pm 0.02$ \\
\hline $16 a$ & $0.33 \pm 0.10$ & $0.17 \pm 0.06$ & $0.55 \pm 0.30$ & $0.36 \pm 0.036$ \\
\hline $16 b$ & $0.25 \pm 0.01$ & $0.19 \pm 0.02$ & $0.50 \pm 0.40$ & $0.26 \pm 0.030$ \\
\hline $16 \mathrm{c}$ & $0.058 \pm 0.014$ & $0.041 \pm 0.007$ & $0.093 \pm 0.022$ & $0.059 \pm 0.001$ \\
\hline 16d & $0.14 \pm 0.08$ & $0.12 \pm 0.02$ & $0.16 \pm 0.03$ & $0.083 \pm 0.004$ \\
\hline $16 e$ & $0.065 \pm 0.003$ & $0.16 \pm 0.00$ & $0.054 \pm 0.014$ & $0.14 \pm 0.03$ \\
\hline $16 \mathbf{i}$ & $0.19 \pm 0.02$ & $0.22 \pm 0.01$ & $0.13 \pm 0.01$ & $0.18 \pm 0.01$ \\
\hline $16 j$ & $0.058 \pm 0.01$ & $0.12 \pm 0.00$ & $0.075 \pm 0.012$ & $0.14 \pm 0.04$ \\
\hline $16 k$ & $0.086 \pm 0,003$ & $0.17 \pm 0.01$ & $0.079 \pm 0.031$ & $0.16 \pm 0.04$ \\
\hline 161 & $0.053 \pm 0.006$ & $0.042 \pm 0.001$ & $0.082 \pm 0.063$ & $0.041 \pm 0.008$ \\
\hline $16 \mathrm{~m}$ & $0.040 \pm 0.002$ & $0.037 \pm 0.005$ & $0.039 \pm 0.000$ & $0.047 \pm 0.019$ \\
\hline $16 n$ & $0.026 \pm 0.007$ & $0.012 \pm 0.008$ & $0.033 \pm 0.000$ & $0.029 \pm 0.003$ \\
\hline Colchicine (5) & $0.010 \pm 0.0006$ & $0.013 \pm 0.0004$ & $0.0087 \pm 0.0001$ & $0.0038 \pm 0.0011$ \\
\hline CA-4P (7) & $0.013 \pm 0.0023$ & $0.011 \pm 0.001$ & $0.013 \pm 0.001$ & $0.0029 \pm 0.0001$ \\
\hline
\end{tabular}

${ }^{\mathrm{a}} \mathrm{IC}_{50}(50 \%$ inhibitory concentration) is given as the mean $\pm \mathrm{SD}$ of three independent experiments.

\subsection{Tubulin binding.}

In order to corroborate whether the antiproliferative activity of these diarylethers was derived from their interaction with tubulin, the effect on dimeric tubulin polymerization into microtubules was tested in a turbidimetric assay including podophylotoxin as control. As shown in Figure 4, at the tested concentration all compounds displayed a destabilizing effect of tubulin polymerization similar to that of podophylotoxin.

In addition, binding affinities for all final compounds to tubulin were determined by a competition experiment with R-PT as previously described.[16, 25] The data obtained are collected in Table 2. All the compounds showed a remarkable affinity for tubulin, with $\mathrm{K}_{\mathrm{b}}$ values ranging from $10^{6}$ to $10^{7} \mathrm{M}^{-1}$. The best $\mathrm{K}_{\mathrm{b}}$ values correspond to compounds $16 \mathrm{c}\left(\mathrm{K}_{\mathrm{b}}=\right.$ $\left.15.65 \times 10^{6}\right), \mathbf{1 6 m}\left(\mathrm{K}_{\mathrm{b}}=11.75 \times 10^{6} \mathrm{~T}\right)$ and $\mathbf{1 6 n}\left(\mathrm{K}_{\mathrm{b}}=18.05 \pm \times 10^{6}\right)$, and are similar to that of colchicine $\left(\mathrm{K}_{\mathrm{b}}=11.6 \times 10^{6} \mathrm{M}^{-1}\right)$. Interestingly, these compounds were also among the ones that provided better antiproliferative activity in cell culture. 


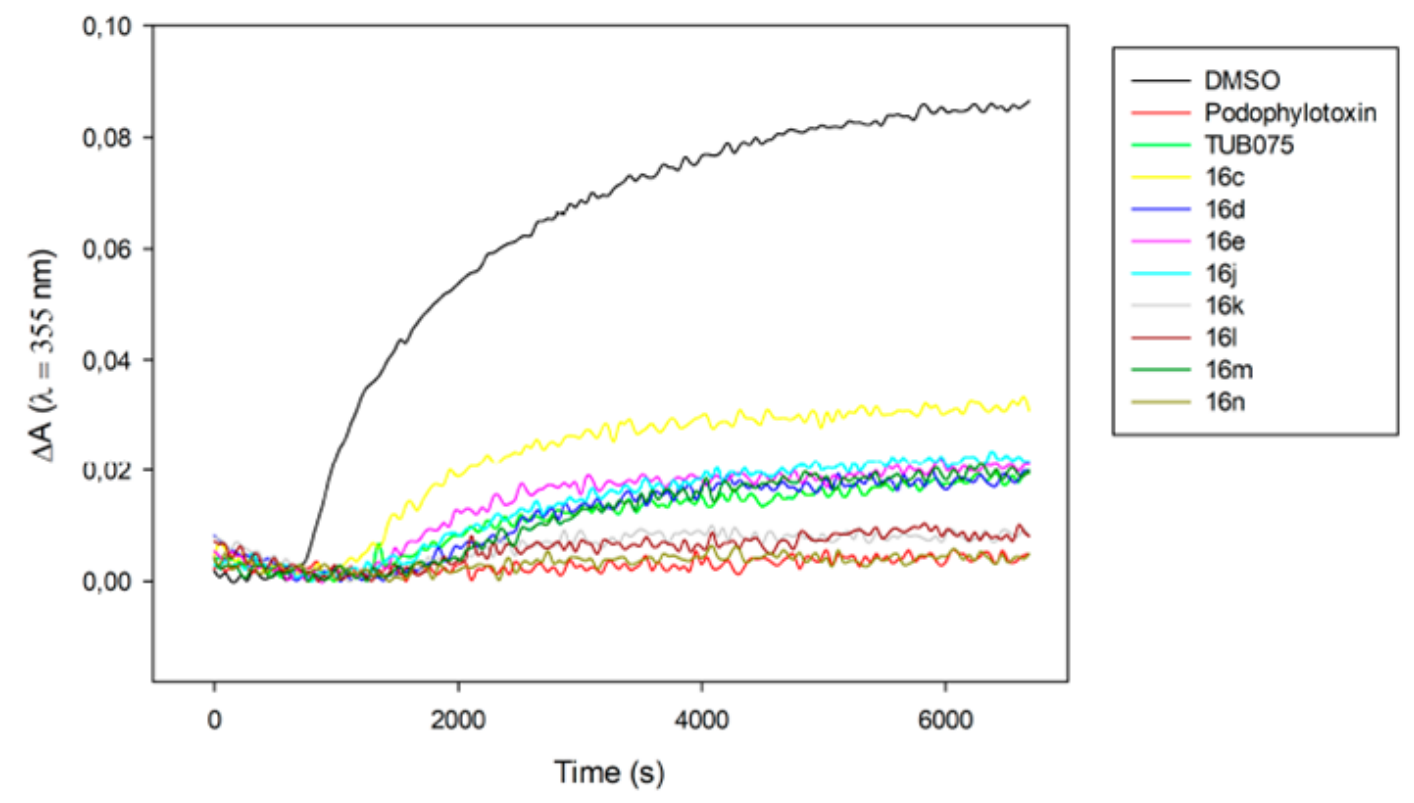

Figure 4. Time course of tubulin polymerization at $37^{\circ} \mathrm{C}$ measured by $350 \mathrm{~nm}$ turbidimetry. Tubulin concentration: $25 \mu \mathrm{M}$, compounds 16c-n $30 \mu \mathrm{M}$

Table 2. Binding constants for $\alpha \beta$-tubulin

\begin{tabular}{ll}
\hline Comp & ${\mathrm{Kb}\left(\mathrm{M}^{-1}\right)}$ \\
\hline Colchicine (5) & $11.6 \times 10^{6(\mathrm{a})[26]}$ \\
Podophyllotoxin & $1.8 \times 10^{6(\mathrm{a})[27]}$ \\
R-PT & $3.2 \times 10^{6[25]}$ \\
TUB075 (10) & $(13 \pm 2) \times 10^{6(\mathrm{a})}$ \\
$\mathbf{1 6 c}$ & $(15.65 \pm 5.55) \times 10^{6(\mathrm{a})}$ \\
$\mathbf{1 6 d}$ & $(5.23 \pm 0.24) \times 10^{6(\mathrm{a})}$ \\
$\mathbf{1 6 e}$ & $(3.13 \pm 0.11) \times 10^{6(\mathrm{a})}$ \\
$\mathbf{1 6 j}$ & $(6.46 \pm 0.91) \times 10^{6(\mathrm{a}}$ \\
$\mathbf{1 6 k}$ & $(5.56 \pm 1.25) \times 10^{6(\mathrm{a})}$ \\
$\mathbf{1 6 l}$ & $(11.75 \pm 2.95) \times 10^{6(\mathrm{a})}$ \\
$\mathbf{1 6 m}$ & $(18.05 \pm 8.05) \times 10^{6(\mathrm{a})}$ \\
$\mathbf{1 6 n}$ &
\end{tabular}

${ }^{a} \overline{\text { At } 25^{\circ} \mathrm{C} .{ }^{b} \text { Mean value of three experiments } \pm \text { StdError }}$ 


\subsection{Cell cycle experiments}

Compounds $16 \mathrm{~m}$ and $\mathbf{1 6 n}$, two of the most active derivatives in this series, were selected to further investigate their antimitotic behaviour due to cell cycle arrest. Thus, we performed cell cycle analysis on HMEC- 1 cells at different concentrations $(0.016,0.08$ and $0.4 \mu \mathrm{M})$ for $24 \mathrm{~h}$. As shown in Figure 5, control (untreated) cells showed the typical distribution pattern of proliferating cells while treatment with 0.08 or $0.4 \mu \mathrm{M}$ of $16 \mathbf{m}$ (Figure $5 \mathrm{~A}$ ) or $\mathbf{1 6 n}$ (Figure 6B) caused an accumulation in $\mathrm{G} 2 / \mathrm{M}$ phase, indicating antimitotic activity. Cell cycle analysis has also been performed with compounds $\mathbf{1 6} \mathbf{m}$ and $\mathbf{1 6} \mathbf{n}$ in HeLa cells, using colchicine as reference compound, with similar results (Figure S1).
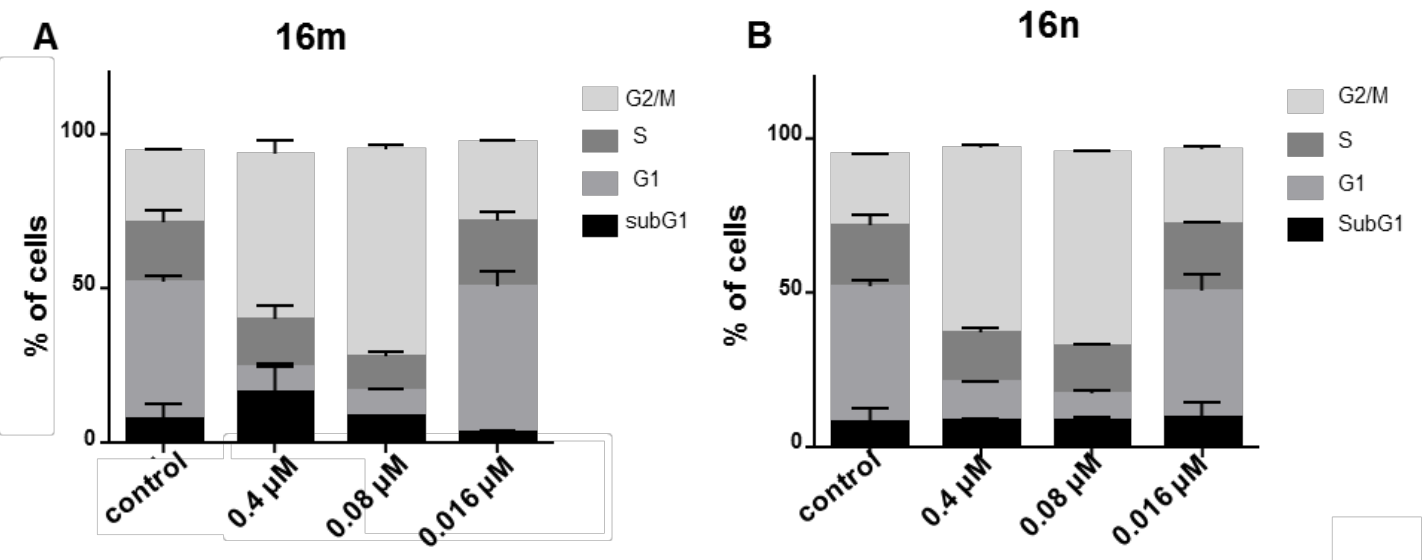

Figure 5. Flow cytometric analysis of cell cycle distribution of HMEC-1 cells treated for $24 \mathrm{~h}$ with different concentrations of $\mathbf{1 6 m}$ (a), 16n (b).

2.6 Vascular disrupting activity.

It is well established that compounds binding at the colchicine site in tubulin are able to destroy the vasculature network formed by endothelial cells. HMEC-1 cells were seeded on top of matrigel and after $3 \mathrm{~h}$ a network of endothelial cells is visible (control). Then derivatives $\mathbf{1 6} \mathbf{m}$ or 16n were added at different concentrations $(2,0.4$ and $0.08 \mu \mathrm{M})$. As can be seen in Figure 6 the addition of the compounds led to vascular disrupting activity in a dose-dependent manner, being visible still at $0.4 \mu \mathrm{M}$. 
A

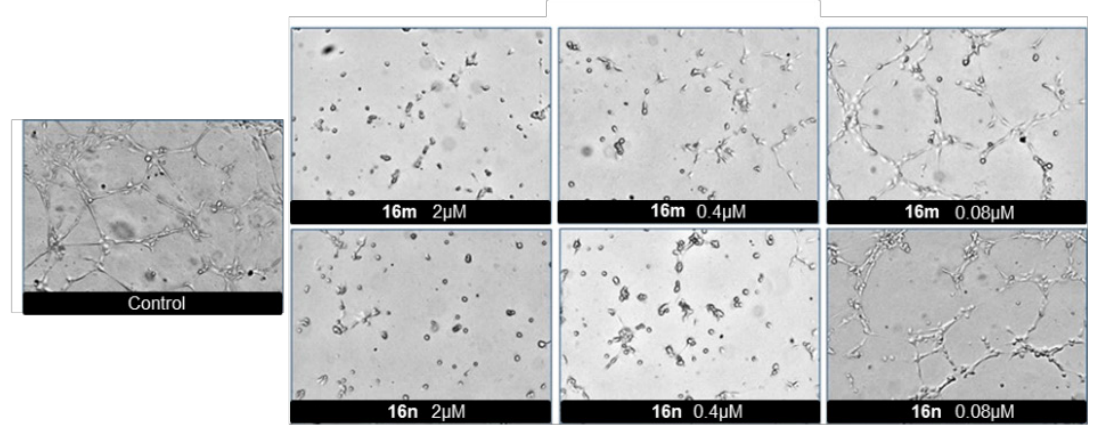

B
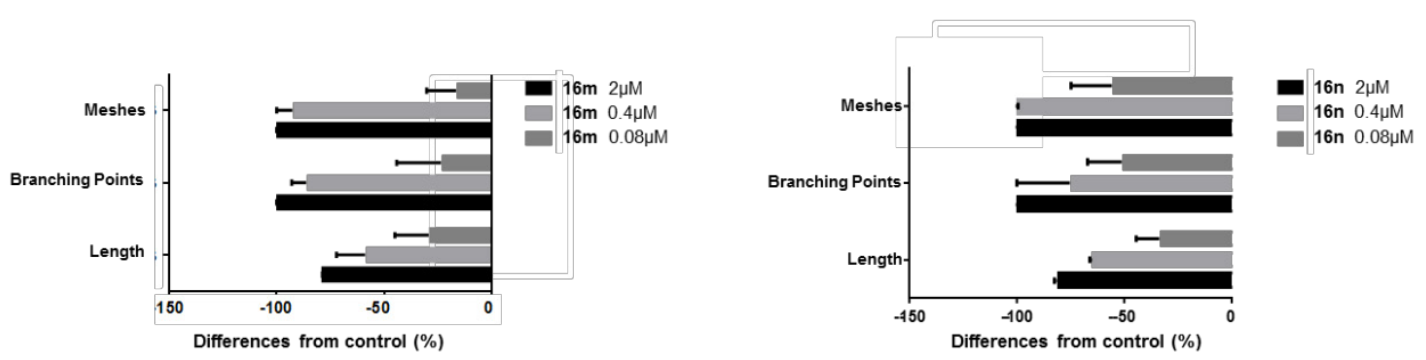

Figure 6. (A) Vascular disrupting effects of $\mathbf{1 6 m}$ and 16n. (B) After $90 \mathrm{~min}$. the number of meshes, branching points and length of the tubes were quantified using Image J analysis.

\subsection{Docking studies.}

To gain a better understanding on the potency and the binding mode of the most potent compound 16n to tubulin, a docking study was performed using the coordinates of the TUB075-tubulin complex (pdb id: 6KFJ) as template. The best docking pose of $\mathbf{1 6 n}$ into the colchicine domain in tubulin (Figure 7A) showed that regions A, B, C and D of 16n (showed in cyan sticks in Figure 7A) occupies the same pocket as TUB075 (represented in nude sticks) sharing also the same orientation, which allows 16n to keep the crucial hydrogen-bond interaction with Glu200, as reported for TUB075. Regarding the new ring E, it is directed towards the interface between $\alpha$ and $\beta$ subunits and the amino group present in this ring $\mathrm{E}$ is at hydrogen bond distance $(2.5 \AA)$ to the backbone carbonyl of Thro179, which is located in the aT5-loop. Moreover, superposition of this predicted binding mode of 16n and the tubulinDAMA-colchicine complex (Figure 7B) showed that ring $\mathrm{E}$ is overlapping with the tropone ring of DAMA-colchicine, thus confirming our rational design of these new derivatives. 

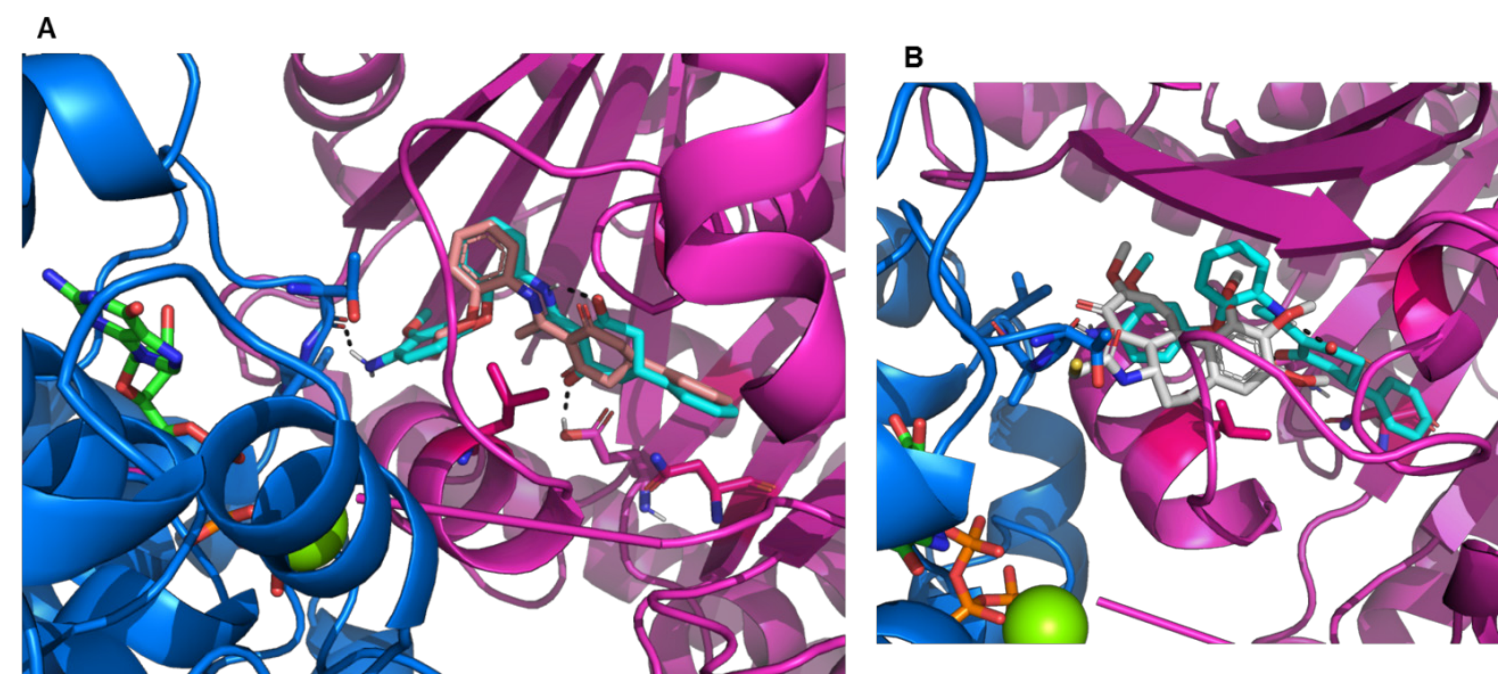

Figure 7. (A) Predicted binding mode of 16n (cyan) in the colchicine domain of $\alpha \beta$-tubulin ( $\alpha$-subunit in blue and $\beta$ subunit in magenta) and overlap with TUB075 (nude). Dashed lines indicate hydrogen bonds and selected interaction residues are shown in sticks and labelled. (B) Superposition of 16n (cyan) and DAMA-colchicine (white)

\section{Conclusions}

Taken advantage of the high resolution X-ray structure of the cyclohexanedione derivative TUB075 bound to $\alpha \beta$-tubulin, a detailed structural comparison with the tubulin-DAMAcolchicine complex has revealed a significant conformational change of the $\alpha \mathrm{T} 5$ loop, that closed the TUB075 binding site in the tubulin-TUB075 complex while it was flipped out in the DAMA-colchicine structure. Applying the computational tool cGRILL to the tubulin-DAMAcolchicine complex, and using $\mathrm{CH}_{3}$ probe, a new potential binding area barely explored by TUB075 at the colchicine site was identified. Thus, a series of diphenyl ether derivatives has been synthesized and tested. The introduction of an extra aromatic ring in the structure of TUB075 has led to highly potent antiproliferative compounds, being compound 16n, with a methoxy group at 3 and an amino group at 4 , the most active among them, with $\mathrm{IC}_{50}$ values between 0.012 and $0.033 \mu \mathrm{M}$, and a tubulin binding constant value of $18.05 \pm \times 10^{6} \mathrm{M}^{-1}$, similar to that of colchicine $\left(\mathrm{K}_{\mathrm{b}}=11.6 \times 10^{6} \mathrm{M}^{-1}\right)$. Moreover, additional biological studies have showed that compounds $\mathbf{1 6 n}$ and $\mathbf{1 6} \mathbf{m}$ held antimitotic activity by an accumulation of cells in G2/M phase and a dose-dependent vascular disrupting activity in the low micromolar range. 


\section{Experimental}

\subsection{Chemistry procedures}

Melting points were obtained on a Reichert-Jung Kofler apparatus and are uncorrected. The elemental analysis was performed with a Heraeus CHN-O-RAPID instrument. The elemental compositions of the compounds agreed to within $\pm 0.4 \%$ of the calculated values.

Electrospray mass spectra were measured on a quadrupole mass spectrometer equipped with an electrospray source (Hewlett-Packard, LC/MS HP 1100).

${ }^{1} \mathrm{H}$ and ${ }^{13} \mathrm{C}$ NMR spectra were recorded on a Varian INNOVA 300 operating at $299 \mathrm{MHz}\left({ }^{1} \mathrm{H}\right)$ and $75 \mathrm{MHz}\left({ }^{13} \mathrm{C}\right)$, respectively, a Varian INNOVA-400 operating at $399 \mathrm{MHZ}\left({ }^{1} \mathrm{H}\right)$ and 99 $\mathrm{MHz}\left({ }^{13} \mathrm{C}\right)$, respectively, and a VARIAN SYSTEM-500 operating a $499 \mathrm{MHz}\left({ }^{1} \mathrm{H}\right)$ and 125 $\mathrm{MHz}\left({ }^{13} \mathrm{C}\right)$, respectively. Monodimensional ${ }^{1} \mathrm{H}$ and ${ }^{13} \mathrm{C}$ spectra were obtained using standard conditions. 2D inverse proton detected heteronuclear one-bond shift correlation spectra were obtained using the Pulsed Field Gradient HSQC pulse sequence. Data were collected in a $2048 \times 512$ matrix with a spectral width of $3460 \mathrm{~Hz}$ in the proton domain and $22500 \mathrm{~Hz}$ in the carbon domain, and processed in a 2048x1024 matrix. The experiment was optimized for one bond heteronuclear coupling constant of $150 \mathrm{~Hz}$. 2D inverse proton detected heteronuclear long range shift correlation spectra were obtained using the Pulsed Field Gradient HMBC pulse sequence. The HMBC experiment was acquired in the same conditions that HSQC experiment and optimized for long range coupling constants of $7 \mathrm{~Hz}$

Analytical TLC was performed on silica gel $60 \mathrm{~F}_{254}$ (Merck) precoated plates $(0.2 \mathrm{~mm})$. Spots were detected under UV light $(254 \mathrm{~nm})$ and/or charring with ninhydrin or phosphomolibdic acid.

Separations on silica gel were performed by preparative centrifugal circular thin-layer chromatography (CCTLC) on a Chromatotron ${ }^{\mathrm{R}}$ (Kiesegel $60 \mathrm{PF}_{254}$ gipshaltig (Merck)), with layer thickness of 1 and $2 \mathrm{~mm}$ and flow rate of 4 or $8 \mathrm{~mL} / \mathrm{min}$, respectively. Flash column chromatography was performed in a Biotage Horizon instrument.

Microwave reactions were performed using the Biotage Initiator 2.0 single-mode cavity instrument from Biotage (Uppsala). Experiments were carried out in sealed microwave process vials utilizing the standard absorbance level ( $400 \mathrm{~W}$ maximum power). The temperature was measured with an IR sensor on the outside of the reaction vessel.

\subsubsection{General procedure [19] for the synthesis of 2-nitrodiphenyl ethers (General procedure A).}

To a mixture of $\mathrm{Cs}_{2} \mathrm{CO}_{3}(1.0 \mathrm{mmol})$ and the substituted phenol $(1.2 \mathrm{mmol})$ in anhydrous acetonitrile (2.5 mL/mmol), 1-fluoro-2-nitrobenzene (11) (1.0 mmol) was added dropwise while stirring under argon. After $2-5 \mathrm{~h}$ at $80{ }^{\circ} \mathrm{C}$, water $(20 \mathrm{~mL})$ and sat. aq. $\mathrm{NaHCO}_{3}$ solution $(20 \mathrm{~mL})$ was added and the mixture was extracted with ethyl acetate. The organic layer was dried over $\mathrm{Na}_{2} \mathrm{SO}_{4}$, concentrated, and purified by flash chromatography (hexane/ethyl acetate). 


\subsubsection{1-(4-Fluorophenoxy)-2-nitrobenzene (13a)}

Following the general procedure $\mathrm{A}$, to a mixture of $\mathrm{Cs}_{2} \mathrm{CO}_{3}(482 \mathrm{mg}, 1.48 \mathrm{mmol})$ and 3fluorophenol (12a) (162 $\mu \mathrm{L}, 1.70 \mathrm{mmol})$ in $\mathrm{CH}_{3} \mathrm{CN}$ (3.6 mL), 1-fluoro-2-nitrobenzene (11) (156 $\mu \mathrm{L}, 1.48 \mathrm{mmol}$ ) was added. After $4 \mathrm{~h}$ at $80^{\circ} \mathrm{C}$, the residue was worked up and purified by flash chromatography (hexane/ethyl acetate, $10: 1)$ to yield $310 \mathrm{mg}(90 \%)$ of 13a as a yellow oil. ${ }^{1} \mathrm{H}$ NMR (DMSO- $d_{6}, 300 \mathrm{MHz}$ ): $\delta 6.88(\mathrm{dd}, J=8.3,2.4 \mathrm{~Hz}, 1 \mathrm{H}, \mathrm{Ar}), 7.00$ (m, $1 \mathrm{H}, \mathrm{Ar}$ ), 7.06 (dd, $J$ $=8.5,2.3 \mathrm{~Hz}, 1 \mathrm{H}, \mathrm{Ar}), 7.27(\mathrm{dd}, J=8.3,1.2 \mathrm{~Hz}, 1 \mathrm{H}, \mathrm{Ar}), 7.37-7.53(\mathrm{~m}, 2 \mathrm{H}, \mathrm{Ar}), 7.74(\mathrm{~m}, 1 \mathrm{H}$, Ar), 8.10 (dd, $J=8.2,1.7 \mathrm{~Hz}, 1 \mathrm{H}, \mathrm{Ar})$. MS (ES, positive mode): $234(\mathrm{M}+\mathrm{H})^{+} .{ }^{1} \mathrm{H}$ NMR data are similar to those previously described [28].

\subsubsection{1-(4-Chlorophenoxy)-2-nitrobenzene (13b)}

Following the general procedure $\mathrm{A}$, to a mixture of $\mathrm{Cs}_{2} \mathrm{CO}_{3}(463 \mathrm{mg}, 1.42 \mathrm{mmol})$ and 4chlorophenol (12b) $(167 \mu \mathrm{L}, 1.70 \mathrm{mmol})$ in $\mathrm{CH}_{3} \mathrm{CN}$ (3.6 mL), 1-fluoro-2-nitrobenzene (11) $(149 \mu \mathrm{L}, 1.42 \mathrm{mmol})$ was added. After $2 \mathrm{~h}$ at $80^{\circ} \mathrm{C}$, the residue was worked up and purified by flash chromatography (hexane/ethyl acetate 10:1) to yield $864 \mathrm{mg}(99 \%)$ of $\mathbf{1 3 b}$ as a yellow oil. ${ }^{1} \mathrm{H}$ NMR (DMSO- $d_{6}, 300 \mathrm{MHz}$ ): $\delta 7.00-7.14$ (m, 2H, Ar), 7.22 (dd, $J=8.4,1.2 \mathrm{~Hz}, 1 \mathrm{H}, \mathrm{Ar}$ ), 7.41 (m, 1H, Ar), 7.45-7.52 (m, 2H, Ar), 7.72 (m, 1H, Ar), 8.09 (dd, J=8.1, 1.7 Hz, 1H, Ar). ${ }^{1} \mathrm{H}$ NMR data are similar to those previously described [28].

\subsubsection{1-(3-Methoxyphenoxy)-2-nitrobenzene (13c)}

Following the general procedure $\mathrm{A}$, to a mixture of $\mathrm{Cs}_{2} \mathrm{CO}_{3}(925 \mathrm{mg}, 2.84 \mathrm{mmol})$ and 3methoxyphenol (12c) $(373 \mu \mathrm{L}, 3.40 \mathrm{mmol})$ in $\mathrm{CH}_{3} \mathrm{CN}$ (7.1 mL), 1-fluoro-2-nitrobenzene (11) $\left(299 \mu \mathrm{L}, 2.84 \mathrm{mmol}\right.$ ) was added. After $3 \mathrm{~h}$ at $80^{\circ} \mathrm{C}$, the residue was worked up and purified by flash chromatography (hexane/ethyl acetate, 5:1) to yield $615 \mathrm{mg}(88 \%)$ of $\mathbf{1 3 c}$ as a yellow oil. ${ }^{1} \mathrm{H}$ NMR (DMSO- $d_{6}, 400 \mathrm{MHz}$ ): $\delta 3.75$ (s, 3H, $\mathrm{CH}_{3}$ ), 6.59 (ddd, $J=8.2,2.3,0.8 \mathrm{~Hz}, 1 \mathrm{H}, \mathrm{Ar}$ ), 6.67 (t, $J=2.4 \mathrm{~Hz}, 1 \mathrm{H}, \mathrm{Ar}$ ), 6.79 (ddd, $J=8.4,2.4,0.8 \mathrm{~Hz}, 1 \mathrm{H}, \mathrm{Ar}$ ), 7.16 (dd, $J=8.4,1.2 \mathrm{~Hz}$, $1 \mathrm{H}, \mathrm{Ar}$ ), 7.32 (t, $J=8.2 \mathrm{~Hz}, 1 \mathrm{H}, \mathrm{Ar}$ ), 7.37 (ddd, $J=8.4,7.4,1.2 \mathrm{~Hz}, 1 \mathrm{H}, \mathrm{Ar}$ ), 7.69 (ddd, $J=8.3$, 7.4, $1.7 \mathrm{~Hz}, 1 \mathrm{H}, \mathrm{Ar}), 8.06$ (dd, $J=8.1,1.7 \mathrm{~Hz}, 1 \mathrm{H}, \mathrm{Ar}$ ). MS (ES, positive mode): 246 $(\mathrm{M}+\mathrm{H}){ }^{+} .{ }^{1} \mathrm{H}$ NMR data are similar to those previously described [28].

\subsubsection{1-(4-Methoxyphenoxy)-2-nitrobenzene (13d)}

Following the general procedure $\mathrm{A}$, to a mixture of $\mathrm{Cs}_{2} \mathrm{CO}_{3}(1.15 \mathrm{~g}, 3.54 \mathrm{mmol})$ and $4-$ methoxyphenol (12d) $(528 \mathrm{mg}, 4.25 \mathrm{mmol})$ in $\mathrm{CH}_{3} \mathrm{CN}$ (9 mL), 1-fluoro-2-nitrobenzene (11) ( $374 \mu \mathrm{L}, 3.54 \mathrm{mmol}$ ) was added dropwise while stirring under argon. After $3 \mathrm{~h}$ at $80{ }^{\circ} \mathrm{C}$, the residue was worked up and purified by flash chromatography (hexane/ethyl acetate 10:1) to yield $864 \mathrm{mg}(99 \%)$ of $\mathbf{1 3 d}$ as a yellow solid. Mp 76-78 ${ }^{\circ} \mathrm{C}\left(\operatorname{lit}[29] 75-76.5{ }^{\circ} \mathrm{C}\right) ;{ }^{1} \mathrm{H}$ NMR (DMSO-d $\left.d_{6}, 300 \mathrm{MHz}\right): \delta 3.76$ (s, 3H, $\mathrm{CH}_{3}$ ), 6.96-7.03 (m, 3H, Ar), 7.04-7.12 (m, 2H, Ar), 7.28 (m, 1H, Ar), 7.63 (m, 1H, Ar), 8.02 (dd, $J=8.1,1.7 \mathrm{~Hz}, 1 \mathrm{H}, \mathrm{Ar})$. MS (ES, positive mode): 246 $(\mathrm{M}+\mathrm{H})^{+} .{ }^{1} \mathrm{H}$ NMR data are similar to those previously described [19]. 


\subsubsection{1,2-Dimethoxy-4-(2-nitrophenoxy)benzene (13e)}

Following the general procedure $\mathrm{A}$, to a mixture of $\mathrm{Cs}_{2} \mathrm{CO}_{3}(925 \mathrm{mg}, 2.84 \mathrm{mmol})$ and 3,4dimethoxyphenol (12e) (525 mg, $3.40 \mathrm{mmol})$ in $\mathrm{CH}_{3} \mathrm{CN}$ (7.1 mL), 1-fluoro-2-nitrobenzene (11) $(299 \mu \mathrm{L}, 2.84 \mathrm{mmol})$ was added. After $5 \mathrm{~h}$ at $80^{\circ} \mathrm{C}$, the residue was worked up and purified by flash chromatography (hexane/ethyl acetate, 10:1) to yield $767 \mathrm{mg}(97 \%)$ of 13e as a yellow oil. ${ }^{1} \mathrm{H}$ NMR (DMSO-d $\left.d_{6}, 400 \mathrm{MHz}\right): \delta 3.74\left(\mathrm{~s}, 3 \mathrm{H}, \mathrm{CH}_{3}\right), 3.76\left(\mathrm{~s}, 3 \mathrm{H}, \mathrm{CH}_{3}\right), 6.61$ (dd, $J=8.7,2.8$ $\mathrm{Hz}, 1 \mathrm{H}, \mathrm{Ar}$ ), 6.85 (d, $J=2.8 \mathrm{~Hz}, 1 \mathrm{H}, \mathrm{Ar}$ ), 6.97-7.02 (m, 2H, Ar), 7.27 (ddd, $J=8.2,7.4,1.2 \mathrm{~Hz}$, $1 \mathrm{H}, \mathrm{Ar}$ ), 7.63 (ddd, $J=8.5,7.4,1.7 \mathrm{~Hz}, 1 \mathrm{H}, \mathrm{Ar}$ ), 8.02 (dd, $J=8.1,1.7 \mathrm{~Hz}, 1 \mathrm{H}, \mathrm{Ar}$ ). MS (ES, positive mode): $276(\mathrm{M}+\mathrm{H})^{+} .{ }^{1} \mathrm{H}$ NMR data are similar to those previously described [19].

\subsubsection{6. tert-Butyl (3-(2-nitrophenoxy)phenyl)carbamate (13f)}

Following the general procedure $\mathrm{A}$, to a mixture of $\mathrm{Cs}_{2} \mathrm{CO}_{3}(694 \mathrm{mg}, 2.13 \mathrm{mmol})$ and tert-butyl (3-hydroxyphenyl)carbamate (12f)[20] (534 mg, $2.55 \mathrm{mmol}$ ) in $\mathrm{CH}_{3} \mathrm{CN}$ (5.3 mL), 1-fluoro-2nitrobenzene (11) $(224 \mu \mathrm{L}, 2.13 \mathrm{mmol})$ was added dropwise while stirring under argon. After 4 $\mathrm{h}$ at $80{ }^{\circ} \mathrm{C}$, the residue was worked up and purified by flash chromatography (hexane/ethyl acetate, $4: 1)$ to yield $650 \mathrm{mg}(92 \%)$ of $\mathbf{1 3 f}$ as a yellow oil. ${ }^{1} \mathbf{H}$ NMR (DMSO- $d_{6}, 400 \mathrm{MHz}$ ): $\delta$ 1.44 (s, 9H, $\left.\left(\mathrm{CH}_{3}\right)_{3}\right), 6.64$ (ddd, $\left.J=7.8,2.3,1.4 \mathrm{~Hz}, 1 \mathrm{H}, \mathrm{Ar}\right), 7.15$ (dd, $J=8.4,1.2 \mathrm{~Hz}, 1 \mathrm{H}, \mathrm{Ar}$ ), 7.22-7.31 (m, 3H, Ar), 7.36 (ddd, $J=8.3,7.5,1.2 \mathrm{~Hz}, 1 \mathrm{H}, \mathrm{Ar}$ ), 7.69 (ddd, $J=8.2,7.4,1.7 \mathrm{~Hz}$, Ar), 8.06 (dd, $J=8.2,1.7 \mathrm{~Hz}, 1 \mathrm{H}, \mathrm{Ar}), 9.51$ (br s, 1H, NH). MS (ES, positive mode): 331 $(\mathrm{M}+\mathrm{H})^{+}, 661(2 \mathrm{M}+\mathrm{H})^{+}$.

\subsubsection{7. tert-Butyl (4-(2-nitrophenoxy)phenyl)carbamate (13g)}

Following the general procedure $\mathrm{A}$, to a mixture of $\mathrm{Cs}_{2} \mathrm{CO}_{3}(436 \mathrm{mg}, 1.34 \mathrm{mmol})$ and tertbutyl(4-hydroxyphenyl)carbamate (12g)[21] (337 mg, $1.61 \mathrm{mmol})$ in $\mathrm{CH}_{3} \mathrm{CN}$ (3.5 mL), 1fluoro-2-nitrobenzene (11) $(141 \mu \mathrm{L}, 1.34 \mathrm{mmol})$ was added dropwise while stirring under argon. After $3 \mathrm{~h}$ at $80{ }^{\circ} \mathrm{C}$, the residue was worked up and purified by flash chromatography (hexane/ethyl acetate, $4: 1)$ to yield $512 \mathrm{mg}(96 \%)$ of $\mathbf{1 3 g}$ as yellow oil. ${ }^{1} \mathrm{H}$ NMR (DMSO- $d_{6}$, $400 \mathrm{MHz}$ ): $\delta 1.47$ (s, 9H, $\left.\left(\mathrm{CH}_{3}\right)_{3}\right), 6.99-7.05$ (m, 3H, Ar), 7.29 (ddd, $J=8.3,7.4,1.2 \mathrm{~Hz}, 1 \mathrm{H}$, Ar), 7.45-7.53 (m, 2H, Ar), 7.64 (ddd, $J=8.5,7.4,1.7 \mathrm{~Hz}, 1 \mathrm{H}, \mathrm{Ar}), 8.02$ (dd, $J=8.1,1.7 \mathrm{~Hz}$, 1H, Ar), 9.44 (br s, 1H, NH). MS (ES, positive mode): $353(\mathrm{M}+\mathrm{Na})^{+}, 661(2 \mathrm{M}+\mathrm{H})^{+}$.

\subsubsection{8. tert-Butyl (2-methoxy-4-(2-nitrophenoxy)phenyl)carbamate (13h)}

Following the general procedure $\mathrm{A}$, to a mixture of $\mathrm{Cs}_{2} \mathrm{CO}_{3}(227 \mathrm{mg}, 0.70 \mathrm{mmol})$ and tertbutyl(4-hydroxy-2-methoxyphenyl)carbamate (12h)[22] (200 mg, $0.84 \mathrm{mmol})$ in $\mathrm{CH}_{3} \mathrm{CN}$ (1.8 $\mathrm{mL})$, 1-fluoro-2-nitrobenzene (11) $(74 \mu \mathrm{L}, 0.70 \mathrm{mmol})$ was added dropwise while stirring under argon. After $4 \mathrm{~h}$ at $80{ }^{\circ} \mathrm{C}$, the residue was worked up and purified by flash chromatography (hexane/ethyl acetate, $4: 1)$ to yield $212 \mathrm{mg}(96 \%)$ of $\mathbf{1 3 h}$ as a yellow oil. ${ }^{1} \mathrm{H}$ NMR (DMSO- $d_{6}$, $400 \mathrm{MHz}): \delta 1.45\left(\mathrm{~s}, 9 \mathrm{H},\left(\mathrm{CH}_{3}\right)_{3}\right), 3.78\left(\mathrm{~s}, 3 \mathrm{H}, \mathrm{OCH}_{3}\right), 6.58(\mathrm{dd}, J=8.7,2.6 \mathrm{~Hz}, 1 \mathrm{H}, \mathrm{Ar}), 6.87$ (d, $J=2.6 \mathrm{~Hz}, 1 \mathrm{H}, \mathrm{Ar}), 7.08$ (dd, $J=8.4,1.2 \mathrm{~Hz}, 1 \mathrm{H}, \mathrm{Ar}$ ), 7.31 (ddd, $J=8.4,7.4,1.2 \mathrm{~Hz}, 1 \mathrm{H}$, 
Ar), 7.60-7.69 (m, 2H, Ar), 8.02 (br s, 1H, NH), 8.04 (dd, $J=8.2,1.7 \mathrm{~Hz}, 1 \mathrm{H}$, Ar). MS (ES, positive mode): $361(\mathrm{M}+\mathrm{H})^{+}, 383(\mathrm{M}+\mathrm{Na})^{+}, 721(2 \mathrm{M}+\mathrm{H})^{+}$.

\subsubsection{1-(4-(2-Nitrophenoxy)acetophenone (13i)}

Following the general procedure $\mathrm{A}$, to a mixture of $\mathrm{Cs}_{2} \mathrm{CO}_{3}(925 \mathrm{mg}, 2.84 \mathrm{mmol})$ and 4hydroxyacetophenone (12i) $(464 \mathrm{mg}, 3.40 \mathrm{mmol})$ in $\mathrm{CH}_{3} \mathrm{CN}(7.1 \mathrm{~mL})$, 1-fluoro-2-nitrobenzene (11) $(299 \mu \mathrm{L}, 2.84 \mathrm{mmol})$ was added. After $5 \mathrm{~h}$ at $80{ }^{\circ} \mathrm{C}$, the residue was worked up and purified by flash chromatography (dichloromethane/methanol, 20:1) to yield $613 \mathrm{mg}$ (84\%) of 13i as a white solid. Mp 104-106 ${ }^{\circ} \mathrm{C}$ (lit [30] $104.6{ }^{\circ} \mathrm{C}$ ). ${ }^{1} \mathrm{H}$ NMR (DMSO- $d_{6}, 400 \mathrm{MHz}$ ): $\delta 2.56$ (s, 3H, $\mathrm{CH}_{3}$ ), 7.07-7.15 (m, 2H, Ar), 7.37 (dd, $\left.J=8.3,1.2 \mathrm{~Hz}, 1 \mathrm{H}, \mathrm{Ar}\right), 7.50$ (m, 1H, Ar), 7.79 (m, 1H, Ar), 7.98-8.03 (m, 2H, Ar), 8.14 (dd, $J=8.2,1.6 \mathrm{~Hz}, 1 \mathrm{H}, \mathrm{Ar})$. MS (ES, positive mode): $258(\mathrm{M}+\mathrm{H})^{+}, 515(2 \mathrm{M}+\mathrm{H})^{+1} \mathrm{H}$ NMR data are similar to those previously described [30].

\subsubsection{General procedure for the synthesis of 2-aminodiphenyl ethers (General procedure B).}

The corresponding 2-nitrodiphenyl ether was dissolved in ethyl acetate $(12 \mathrm{~mL})$ in a pressure vessel and then $10 \% \mathrm{Pd} / \mathrm{C}$ or $5 \% \mathrm{Pt} / \mathrm{S}$ (catalytic amount) was added. The vessel was hydrogenated at $30 \mathrm{psi}$ for $1-5 \mathrm{~h}$ at room temperature. Then, the reaction mixture was filtered and volatiles were removed under reduced pressure. In most cases, the obtained 2aminodiphenyl ethers were directly used as such in the subsequent reaction without further purification.

\subsubsection{2-(3-Fluorophenoxy)aniline (14a)}

Following the general procedure B, a solution of 13a (431 mg, $1.85 \mathrm{mmol})$ in ethyl acetate (12 $\mathrm{mL}$ ) in the presence of $5 \% \mathrm{Pt} / \mathrm{S}$ (catalytic amount) was subjected to hydrogenation for $2 \mathrm{~h}$ at $\mathrm{rt}$. Then, the reaction mixture was filtered and the solvent was evaporated. The residue was purified by flash chromatography (hexane/ethyl acetate, 5:1) to afford $316 \mathrm{mg}(84 \%)$ of $\mathbf{1 4 a}$ as a colorless oil. ${ }^{1} \mathbf{H}$ NMR (DMSO- $d_{6}, 300 \mathrm{MHz}$ ): $\delta 4.95$ (br s, 2H, $\mathrm{NH}_{2}$ ), 6.52-6.60 (m, 1H, Ar), 6.62-6.72 (m, 2H, Ar), 6.78-6.90 (m, 3H, Ar), 6.95 (m, 1H, Ar), 7.27-7.39 (m, 1H, Ar). MS (ES, positive mode): $246(\mathrm{M}+\mathrm{ACN}+\mathrm{H})^{+} .{ }^{1} \mathrm{H}$ NMR data are similar to those previously described [28].

\subsubsection{2-(4-Chlorophenoxy)aniline (14b)}

Following the general procedure $\mathrm{B}$, a solution of $\mathbf{1 3 b}(63 \mathrm{mg}, 0.252 \mathrm{mmol})$ in ethyl acetate $(12$ $\mathrm{mL}$ ) in the presence of 5\% Pt/S (catalytic amount) was subjected to hydrogenation for $2 \mathrm{~h}$ at $\mathrm{rt}$. Then, the reaction mixture was filtered and the solvent was evaporated. The residue was purified by flash chromatography (hexane/ethyl acetate, 10:3) to afford $41 \mathrm{mg}$ (74\%) of $\mathbf{1 4 b}$ as a colorless oil. ${ }^{1} \mathrm{H}$ NMR (DMSO- $d_{6}, 300 \mathrm{MHz}$ ): $\delta 5.76$ (br s, 2H, $\mathrm{NH}_{2}$ ), 6.76-6.92 (m, 2H, Ar), 6.98-7.18 (m, 4H, Ar), 7.35-7.48 (m, 2H, Ar). MS (ES, positive mode): $220(\mathrm{M}+\mathrm{H})^{+}$with $\mathrm{Cl}$ isotopic distribution. ${ }^{1} \mathrm{H}$ NMR data are similar to those previously described [19].

\subsubsection{2-(3-Methoxyphenoxy)aniline (14c)}


Following the general procedure $\mathrm{B}$, a solution of $13 \mathrm{c}(400 \mathrm{mg}, 1.63 \mathrm{mmol})$ in ethyl acetate $(12$ $\mathrm{mL}$ ) in the presence of $10 \% \mathrm{Pd} / \mathrm{C}$ (catalytic amount) was subjected to hydrogenation for $2 \mathrm{~h}$ at rt. Then, the reaction mixture was filtered and the solvent was evaporated to afford $346 \mathrm{mg}$ (98\%) of $14 \mathrm{c}$ as an orange oil. ${ }^{1} \mathrm{H}$ NMR (DMSO- $\left.d_{6}, 400 \mathrm{MHz}\right): \delta 3.71\left(\mathrm{~s}, 3 \mathrm{H}, \mathrm{CH}_{3}\right), 4.88$ (br s, $2 \mathrm{H}, \mathrm{NH}_{2}$ ), 6.42 (ddd, $\left.J=8.1,2.3,0.9 \mathrm{~Hz}, 1 \mathrm{H}, \mathrm{Ar}\right), 6.47$ (t, $J=2.4 \mathrm{~Hz}, 1 \mathrm{H}, \mathrm{Ar}$ ), 6.55 (ddd, $J=$ 7.9, 7.2, 1.6 Hz, 1H, Ar), 6.62 (ddd, $J=8.3,2.4,0.9 \mathrm{~Hz}, 1 \mathrm{H}, \mathrm{Ar}), 6.80$ (dd, $J=7.9,1.6 \mathrm{~Hz}, 2 \mathrm{H}$, Ar), 6.92 (ddd, $J=8.0,7.3,1.5 \mathrm{~Hz}, 1 \mathrm{H}, \mathrm{Ar}), 7.20$ (t, $J=8.2 \mathrm{~Hz}, 1 \mathrm{H}, \mathrm{Ar})$. MS (ES, positive mode): $216(\mathrm{M}+\mathrm{H})^{+}, 257(\mathrm{M}+\mathrm{ACN}+\mathrm{H})^{+} .{ }^{1} \mathrm{H}$ NMR data are similar to those previously described [19].

\subsubsection{2-(4-Methoxyphenoxy)aniline (14d)}

Following the general procedure B, a solution of 13d $(648 \mathrm{mg}, 2.64 \mathrm{mmol})$ in ethyl acetate $(12$ $\mathrm{mL}$ ) in the presence of $10 \% \mathrm{Pd} / \mathrm{C}$ (catalytic amount) was subjected to hydrogenation for $2 \mathrm{~h}$ at rt. Then, the reaction mixture was filtered and the solvent was evaporated to afford $560 \mathrm{mg}$ (98\%) of 14d as a pink oil. ${ }^{1} \mathrm{H}$ NMR (DMSO- $\left.d_{6}, 300 \mathrm{MHz}\right): \delta 3.71\left(\mathrm{~s}, 1 \mathrm{H}, \mathrm{CH}_{3}\right), 4.88(\mathrm{br} \mathrm{s}, 2 \mathrm{H}$, $\left.\mathrm{NH}_{2}\right), 6.50(\mathrm{~m}, 1 \mathrm{H}, \mathrm{Ar}), 6.66$ (dd, $\left.J=8.0,1.4 \mathrm{~Hz}, 1 \mathrm{H}, \mathrm{Ar}\right), 6.76$ (dd, $\left.J=7.9,1.7 \mathrm{~Hz}, 1 \mathrm{H}, \mathrm{Ar}\right)$, 6.81-6.93 (m, 5H, Ar). MS (ES, positive mode): $216(\mathrm{M}+\mathrm{H})^{+}, 257(\mathrm{M}+\mathrm{ACN}+\mathrm{H})^{+} .{ }^{1} \mathrm{H} \mathrm{NMR}$ data are similar to those previously described [31].

\subsubsection{2-(3,4-Dimethoxyphenoxy)aniline (14e)}

Following the general procedure $\mathrm{B}$, a solution of $13 \mathrm{e}(400 \mathrm{mg}, 1.45 \mathrm{mmol})$ in ethyl acetate (12 $\mathrm{mL}$ ) in the presence of $10 \% \mathrm{Pd} / \mathrm{C}$ (catalytic amount) was subjected to hydrogenation for $2 \mathrm{~h}$ at rt. Then, the reaction mixture was filtered and the solvent was evaporated to afford $343 \mathrm{mg}$ (96\%) of 14e as a white solid. Mp 115-117 ${ }^{\circ} \mathrm{C} .{ }^{1} \mathrm{H}$ NMR (DMSO- $d_{6}, 400 \mathrm{MHz}$ ): $\delta 3.70$ (s, $3 \mathrm{H}$, $\left.\mathrm{OCH}_{3}\right), 3.71$ (s, 3H, $\mathrm{OCH}_{3}$ ), 4.86 (br s, 2H, NH (m, 2H, Ar), $6.77(\mathrm{~m}, 1 \mathrm{H}, \mathrm{Ar}), 6.83-6.89(\mathrm{~m}, 2 \mathrm{H}, \mathrm{Ar})$. MS (ES, positive mode): $246(\mathrm{M}+\mathrm{H})^{+}$, $287(\mathrm{M}+\mathrm{ACN}+\mathrm{H})^{+} .{ }^{1} \mathrm{H}$ NMR data are similar to those previously described [32].

\subsubsection{6. tert-Butyl (3-(2-aminophenoxy)phenyl)carbamate (14f)}

Following the general procedure B, a solution of $\mathbf{1 3 f}(530 \mathrm{mg}, 1.60 \mathrm{mmol})$ in ethyl acetate (12 $\mathrm{mL}$ ) in the presence of $10 \% \mathrm{Pd} / \mathrm{C}$ (catalytic amount) was subjected to hydrogenation for $2 \mathrm{~h}$ at rt. Then, the reaction mixture was filtered and the solvent was evaporated to afford $490 \mathrm{mg}$ (99\%) of 14f as a pink oil. ${ }^{1} \mathrm{H}$ NMR (DMSO- $\left.d_{6}, 400 \mathrm{MHz}\right): \delta 1.44\left(\mathrm{~s}, 9 \mathrm{H},\left(\mathrm{CH}_{3}\right)_{3}\right), 4.85$ (br s, 2H, $\mathrm{NH}_{2}$ ), 6.47 (ddd, $J=8.1,2.4,1.1 \mathrm{~Hz}, 1 \mathrm{H}, \mathrm{Ar}$ ), 6.54 (ddd, $J=7.9,7.2,1.6 \mathrm{~Hz}, 1 \mathrm{H}, \mathrm{Ar}$ ), 6.75 (dd, $J=8.0,1.4 \mathrm{~Hz}, 1 \mathrm{H}, \mathrm{Ar}), 6.79$ (dd, $J=7.9,1.6 \mathrm{~Hz}, 1 \mathrm{H}, \mathrm{Ar}), 6.90$ (ddd, $J=7.9,7.2,1.5 \mathrm{~Hz}$, 1H, Ar), 7.08-7.19 (m, 3H, Ar), 9.37 (br s, 1H, CONH). MS (ES, positive mode): $301(\mathrm{M}+\mathrm{H})^{+}$, $601(2 \mathrm{M}+\mathrm{H})^{+}$.

\subsubsection{7. tert-Butyl (4-(2-aminophenoxy)phenyl)carbamate (14g)}


Following the general procedure $\mathrm{B}$, a solution of $13 \mathrm{~g}$ ( $275 \mathrm{mg}, 0.83 \mathrm{mmol})$ in ethyl acetate $(12$ $\mathrm{mL}$ ) in the presence of $10 \% \mathrm{Pd} / \mathrm{C}$ (catalytic amount) was subjected to hydrogenation for $1 \mathrm{~h}$ at rt. Then, the reaction mixture was filtered and the solvent was evaporated to afford $229 \mathrm{mg}$ (92\%) of $14 f$ as a pink oil. ${ }^{1} \mathrm{H}$ NMR (DMSO- $\left.d_{6}, 400 \mathrm{MHz}\right): \delta 1.46\left(\mathrm{~s}, 9 \mathrm{H},\left(\mathrm{CH}_{3}\right)_{3}\right), 4.86(\mathrm{br} \mathrm{s}$, $\left.2 \mathrm{H}, \mathrm{NH}_{2}\right), 6.50(\mathrm{~m}, 1 \mathrm{H}, \mathrm{Ar}), 6.68(\mathrm{dd}, J=8.1,1.4 \mathrm{~Hz}, 1 \mathrm{H}, \mathrm{Ar}), 6.77$ (dd, $J=7.9,1.7 \mathrm{~Hz}, 1 \mathrm{H}$, Ar), 6.80-6.90 (m, 3H, Ar), 7.38 (d, $J=8.5 \mathrm{~Hz}, 2 \mathrm{H}), 9.24$ (br s, 1H, NH). MS (ES, positive mode): $301(\mathrm{M}+\mathrm{H})^{+}, 601(2 \mathrm{M}+\mathrm{H})^{+}$.

\subsubsection{8. tert-Butyl (4-(2-aminophenoxy)-2-methoxyphenyl)carbamate (14h)}

Following the general procedure B, a solution of $13 \mathbf{h}(190 \mathrm{mg}, 0.53 \mathrm{mmol})$ in ethyl acetate $(12$ $\mathrm{mL}$ ) in the presence of $10 \% \mathrm{Pd} / \mathrm{C}$ (catalytic amount) was subjected to hydrogenation for $4 \mathrm{~h}$ at rt. Then, the reaction mixture was filtered and the solvent was evaporated to afford $150 \mathrm{mg}$ $(86 \%)$ of $14 \mathrm{~h}$ as a pink oil. ${ }^{1} \mathrm{H}$ NMR (DMSO- $\left.d_{6}, 400 \mathrm{MHz}\right): \delta 1.43\left(\mathrm{~s}, 9 \mathrm{H},\left(\mathrm{CH}_{3}\right)_{3}\right), 3.75(\mathrm{~s}, 3 \mathrm{H}$, $\mathrm{OCH}_{3}$ ), 4.87 (br s, 2H, NH$)_{2}, 6.33$ (dd, $\left.J=8.7,2.6 \mathrm{~Hz}, 1 \mathrm{H}, \mathrm{Ar}\right), 6.53$ (m, 1H, Ar), 6.69 (d, $J=$ $2.6 \mathrm{~Hz}, 1 \mathrm{H}, \mathrm{Ar}), 6.75(\mathrm{dd}, J=8.0,1.4 \mathrm{~Hz}, 1 \mathrm{H}, \mathrm{Ar}), 6.79$ (dd, $J=7.9,1.6 \mathrm{~Hz}, 1 \mathrm{H}, \mathrm{Ar}), 6.89$ (m, 1H, Ar), 7.43 (d, $J=8.7 \mathrm{~Hz}, 1 \mathrm{H}, \mathrm{Ar}$ ), 7.88 (br s, 1H, CONH). MS (ES, positive mode): 331 $(\mathrm{M}+\mathrm{H})^{+}, 661(2 \mathrm{M}+\mathrm{H})^{+}$.

4.1.2.9. 1-(4-(2-Aminophenoxy)phenyl)ethan-1-one (14i) and 1-(4-(2Aminophenoxy)phenyl)ethan-1-ol (14j)

Following the general procedure $\mathrm{B}$, a solution of $\mathbf{1 3 i}(250 \mathrm{mg}, 0.97 \mathrm{mmol})$ in ethyl acetate (12 $\mathrm{mL}$ ) in the presence of $10 \% \mathrm{Pd} / \mathrm{C}$ (catalytic amount) was subjected to hydrogenation for $1 \mathrm{~h}$ at rt. Then, the reaction mixture was filtered and the solvent was evaporated. The residue was purified by flash chromatography (hexane/ethyl acetate 2:1). The fastest moving fractions afforded $114 \mathrm{mg}(52 \%)$ of $\mathbf{1 4 i}$ as a colorless oil. ${ }^{1} \mathrm{H}$ NMR (DMSO- $\left.d_{6}, 300 \mathrm{MHz}\right): \delta 2.50(\mathrm{~s}, 1 \mathrm{H}$, $\left.\mathrm{CH}_{3}\right), 4.96$ (br s, 2H, $\mathrm{NH}_{2}$ ), $6.58(\mathrm{~m}, 1 \mathrm{H}, \mathrm{Ar}), 6.79-7.01$ (m, 5H, Ar), 7.92 (d, J=8.4 Hz, 2H, Ar). MS (ES, positive mode): $228(\mathrm{M}+\mathrm{H})^{+}$.

The slowest moving fractions afforded $93 \mathrm{mg}(\mathbf{4 2} \%)$ of $\mathbf{1 4} \mathbf{j}$ as a colorless oil. ${ }^{1} \mathrm{H}$ NMR (DMSO$\left.d_{6}, 300 \mathrm{MHz}\right): \delta 1.29$ (d, $\left.J=6.4 \mathrm{~Hz}, 3 \mathrm{H}, \mathrm{CH}_{3}\right), 4.67$ (m, 1H, CH), 4.87 (br s, 1H, NH), 5.08 (d, $J$ $=4.1 \mathrm{~Hz}, 1 \mathrm{H}, \mathrm{OH}), 6.53(\mathrm{~m}, 1 \mathrm{H}, \mathrm{Ar}), 6.72-6.85(\mathrm{~m}, 4 \mathrm{H}, \mathrm{Ar}), 6.90(\mathrm{~m}, 1 \mathrm{H}, \mathrm{Ar}), 7.27(\mathrm{~d}, J=7.7$ $\mathrm{Hz}, 2 \mathrm{H}, \mathrm{Ar})$. MS (ES, positive mode): $230(\mathrm{M}+\mathrm{H})^{+}$.

4.1.3. General procedure for the reaction of 2-acetylcylcohexanedione with anilines (General procedure $C$ ).

A solution of 2-acetylcylcohexanedione $(\mathbf{1 5})(1.0 \mathrm{mmol})$, the appropiate aniline $(1.5 \mathrm{mmol})$ and $4 \AA$ molecular sieves in toluene $(10 \mathrm{~mL})$ was placed in an Ace pressure tube [23]. Then, the vessel was sealed and heated in a microwave reactor at $110{ }^{\circ} \mathrm{C}$ overnight. After cooling, the solvent was evaporated and the residue was purified by flash chromatography or by CCTLC in the Chromatotron. 
(16a)

Following the general procedure $\mathrm{C}$, an Ace pressure tube was charged with $\mathbf{1 5}$ (189 $\mathrm{mg}, 0.82$ $\mathrm{mmol}), \mathbf{1 4 a}(250 \mathrm{mg}, 1.23 \mathrm{mmol})$ and $4 \AA$ molecular sieves in toluene $(5 \mathrm{~mL})$. The resulting residue was purified by flash chromatography (hexane/ethyl acetate, 5:1) to afford $340 \mathrm{mg}$ (99\%) of 16a as a brown oil. ${ }^{1} \mathrm{H}$ NMR (DMSO- $\left.d_{6}, 400 \mathrm{MHz}\right): \delta 2.44\left(\mathrm{~s}, 3 \mathrm{H}, \mathrm{CH}_{3}\right), 2.50-2.61$ (m, 2H, H-4, H-6), 2.68-2.88 (m, 2H, H-4, H-6), 3.27 (tt, $J=12.0,4.1 \mathrm{~Hz}, 1 \mathrm{H}, \mathrm{H}-5$ ), 6.80 (dd, $J$ $=8.3,2.3 \mathrm{~Hz}, 1 \mathrm{H}, \mathrm{Ar}), 6.90(\mathrm{~m}, 1 \mathrm{H}, \mathrm{Ar}), 7.00(\mathrm{td}, J=8.4,2.5 \mathrm{~Hz}, 1 \mathrm{H}, \mathrm{Ar}), 7.16$ (dd, $J=8.2,1.3$ $\mathrm{Hz}, 1 \mathrm{H}, \mathrm{Ar}), 7.22$ (m, 1H, Ar), 7.28-7.35 (m, 5H, Ar), 7.37-7.47 (m, 2H, Ar), 7.52 (dd, J=7.9, $1.6 \mathrm{~Hz}, 1 \mathrm{H}, \mathrm{Ar}), 14.84$ (br s, $1 \mathrm{H}, \mathrm{NH}) .{ }^{13} \mathrm{C}$ NMR (DMSO- $\left.d_{6}, 100 \mathrm{MHz}\right): \delta 19.8\left(\mathrm{CH}_{3}\right), 36.0(\mathrm{C}-$ 5), 45.2 (C-4, C-6), 105.8 (d, $J=24.8 \mathrm{~Hz}, \mathrm{Ar}), 108.6(\mathrm{NHC}=\underline{\mathrm{C}}), 110.6$ (d, $J=21.1 \mathrm{~Hz}, \mathrm{Ar})$, 113.9 (d, $J=3.0 \mathrm{~Hz}, \mathrm{Ar}$ ), 120.3, 125.00, 126.5, 126.7, 127.7, 128.2, 128.5, 129.6 (Ar), 131.4 (d, $\mathrm{J}=9.9 \mathrm{~Hz}, \mathrm{Ar}), 143.4,149.9,157.5(\mathrm{~d}, J=11.0 \mathrm{~Hz}, \mathrm{Ar}), 162.8$ (d, $J=245.0 \mathrm{~Hz}, \mathrm{Ar}), 172.5$ $(\mathrm{NH} \underline{\mathrm{C}}=\mathrm{C})$. MS (ES, positive mode): $416(\mathrm{M}+\mathrm{H})^{+}$. Anal. calc. for $\left(\mathrm{C}_{26} \mathrm{H}_{22} \mathrm{FNO}_{3}\right): \mathrm{C}, 75.17 ; \mathrm{H}$, 5.34; N, 3.37. Found: C, 74.85; H, 5.46; N, 3.37.

4.1.3.2. 2-(1-((2-(4-Chlorophenoxy)phenyl)amino)ethylidene)-5-phenylcyclohexane-1,3-dione $(16 b)$

Following the general procedure $C$, an Ace pressure tube was charged with 15 (53 $\mathrm{mg}, 0.23$ mmol), 14b (34 mg, $0.15 \mathrm{mmol})$ and $4 \AA$ molecular sieves in toluene $(0.7 \mathrm{~mL})$. The resulting residue was purified by CCTLC (hexane/ethyl acetate, 10:3) to afford $50 \mathrm{mg}(75 \%)$ of $\mathbf{1 6 b}$ as a brown oil. ${ }^{1} \mathrm{H}$ NMR (DMSO-d $d_{6}, 300 \mathrm{MHz}$ ): $\delta 2.45$ (s, 3H, $\mathrm{CH}_{3}$ ), 2.54-2.62 (m, 2H, H-4, H-6), 2.68-2.88 (m, 2H, H-4, H-6), 3.27 (m, 1H, H-5), 6.98-7.04 (m, 2H, Ar), 7.11 (dd, J= 8.2, 1.4 $\mathrm{Hz}, 1 \mathrm{H}, \mathrm{Ar}), 7.22$ (m, 1H, Ar), 7.28-7.34 (m, 5H, Ar), 7.39-7.46 (m, 3H, Ar), 7.51 (dd, J=7.8, $1.7 \mathrm{~Hz}, 1 \mathrm{H}, \mathrm{Ar}), 14.84$ (br s, $1 \mathrm{H}, \mathrm{NH}) .{ }^{13} \mathrm{C}$ NMR (DMSO-d $\left.6,100 \mathrm{MHz}\right): \delta 20.5\left(\mathrm{CH}_{3}\right), 36.7(\mathrm{C}-$ 5), $45.6(\mathrm{C}-4, \mathrm{C}-6), 109.3(\mathrm{NHC}=\underline{\mathrm{C}}), 120.6,120.60,125.0,127.2,127.4,128.2,128.3,128.8$, 129.2, 130.2, 130.6, 144.1, 150.9, 155.7 (Ar), 173.1 (NHC=C). MS (ES, positive mode): 432 $(\mathrm{M}+\mathrm{H})^{+}$with $\mathrm{Cl}$ isotopic distribution pattern. Anal. calc. for $\left(\mathrm{C}_{26} \mathrm{H}_{22} \mathrm{ClNO}_{3}\right): \mathrm{C}, 72.30 ; \mathrm{H}, 5.13$; N, 3.24. Found: C, 71.95; H, 5.20; N, 3.38 .

4.1.3.3. 2-(1-((2-(3-Methoxyphenoxy)phenyl)amino)ethylidene)-5-phenylcyclohexane-1,3-dione (16c)

Following the general procedure $\mathrm{C}$, an Ace pressure tube was charged with $\mathbf{1 5}$ (65 mg, 0.28 mmol), 14c (92 mg, $0.42 \mathrm{mmol})$ and $4 \AA$ molecular sieves in toluene $(1.1 \mathrm{~mL})$. The resulting residue was purified by CCTLC (hexane/ethyl acetate, 10:3) to afford $84 \mathrm{mg}(70 \%)$ of 16c as an oil. ${ }^{1} \mathrm{H}$ NMR (DMSO- $\left.d_{6}, 400 \mathrm{MHz}\right): \delta 2.45$ (s, 3H, $\mathrm{CH}_{3}$ ), 2.53-2.61 (m, 2H, H-4, H-6), 2.682.87 (m, 2H, H-4, H-6), 3.28 (tt, $J=12.1,4.1 \mathrm{~Hz}, 1 \mathrm{H}, \mathrm{H}-5), 3.73$ (s, 1H, $\mathrm{OCH}_{3}$ ), 6.51 (ddd, $J=$ 8.2, 2.4, $0.8 \mathrm{~Hz}, 1 \mathrm{H}, \mathrm{Ar}), 6.59$ (t, $J=2.4 \mathrm{~Hz}, 1 \mathrm{H}, \mathrm{Ar}$ ), 6.74 (ddd, $J=8.3,2.5,0.8 \mathrm{~Hz}, 1 \mathrm{H}, \mathrm{Ar}$ ), 
7.08 (dd, $J=8.2,1.3 \mathrm{~Hz}, 1 \mathrm{H}, \mathrm{Ar}), 7.18-7.24$ (m, 1H, Ar), 7.25-7.37 (m, 6H, Ar), 7.41 (td, $J=$ 7.8, $1.7 \mathrm{~Hz}, 1 \mathrm{H}, \mathrm{Ar}), 7.49$ (dd, $J=7.8,1.6 \mathrm{~Hz}, 1 \mathrm{H}, \mathrm{Ar}$ ), 14.87 (br s, $1 \mathrm{H}, \mathrm{NH}) .{ }^{13} \mathrm{C} \mathrm{NMR}$ (DMSO- $\left.d_{6}, 125 \mathrm{MHz}\right): \delta 19.3\left(\mathrm{CH}_{3}\right), 36.0(\mathrm{C}-5), 45.1$ (C-4, C-6), $55.3\left(\mathrm{OCH}_{3}\right), 104.5(\mathrm{Ar})$, $108.6(\mathrm{NHC}=\underline{\mathrm{C}}), 109.8,110.2,119.6,124.3,126.5,126.7,127.4,128.0,128.5,129.4,130.6$, 143.4, 150.7, 157.1, $160.7(\mathrm{Ar}), 172.5(\mathrm{NHC}=\mathrm{C})$. MS (ES, positive mode): $428(\mathrm{M}+\mathrm{H})^{+}$. Anal. calc. for $\left(\mathrm{C}_{27} \mathrm{H}_{25} \mathrm{NO}_{4}\right)$ : C, 75.86; H, 5.89; N, 3.28. Found: C, 75.55; H, 6.01; N, 3.29.

4.1.3.4. 2-(1-((2-(4-Methoxyphenoxy)phenyl)amino)ethylidene)-5-phenylcyclohexane-1,3-dione (16d)

Following the general procedure C, an Ace pressure tube was charged with $\mathbf{1 5}$ (100 mg, 0.43 mmol), 14d (139 mg, $0.65 \mathrm{mmol})$ and $4 \AA$ molecular sieves in toluene $(1.8 \mathrm{~mL})$. The resulting residue was purified by flash chromatography (dichloromethane/methanol, 10:0.1) to afford 156 mg (85\%) of $\mathbf{1 6 d}$ as a white solid. Mp $137-139{ }^{\circ} \mathrm{C} .{ }^{1} \mathrm{H}$ NMR (DMSO- $d_{6}, 400 \mathrm{MHz}$ ): $\delta 2.48$ (s, $3 \mathrm{H}, \mathrm{CH}_{3}$ ), 2.52-2.64 (m, 2H, H-4, H-6), 2.69-2.90 (m, 2H, H-4, H-6), 3.25 (m, 1H, H-5), 3.75 (s, $\left.3 \mathrm{H}, \mathrm{OCH}_{3}\right), 6.88(\mathrm{dd}, J=8.3,1.3 \mathrm{~Hz}, 1 \mathrm{H}, \mathrm{Ar}), 6.94-7.03(\mathrm{~m}, 4 \mathrm{H}, \mathrm{Ar}), 7.16-7.27(\mathrm{~m}, 2 \mathrm{H}$, Ar), 7.29-7.38 (m, 5H, Ar), 7.45 (dd, $J=7.9,1.6 \mathrm{~Hz}, 1 \mathrm{H}, \mathrm{Ar}), 14.90$ (br s, $1 \mathrm{H}, \mathrm{NH}) .{ }^{13} \mathrm{C} \mathrm{NMR}$ $\left(\mathrm{DMSO}-d_{6}, 100 \mathrm{MHz}\right): \delta 19.9\left(\mathrm{CH}_{3}\right), 36.0(\mathrm{C}-5), 45.6(\mathrm{C}-4, \mathrm{C}-6), 55.5\left(\mathrm{OCH}_{3}\right), 108.6$ $(\mathrm{NHC}=\mathrm{C}), 115.2,117.6,120.6,123.2,126.3,126.5,126.7,127.8,128.5,129.3,143.5,148.7$, 152.0, $156.0(\mathrm{Ar}), 172.6(\mathrm{NHC}=\mathrm{C})$. MS (ES, positive mode): $428(\mathrm{M}+\mathrm{H})^{+}, 855(2 \mathrm{M}+\mathrm{H})^{+}$. Anal. calc. for $\left(\mathrm{C}_{27} \mathrm{H}_{25} \mathrm{NO}_{4}\right)$ : C, 75.86; H, 5.89; N, 3.28. Found: C, 75.71; H, 5.98; N, 3.42.

4.1.3.5. 2-(1-((2-(3,4-Dimethoxyphenoxy)phenyl)amino)ethylidene)-5-phenylcyclohexane-1,3dione $(\mathbf{1 6 e})$

Following the general procedure $C$, an Ace pressure tube was charged with 15 (48 mg, 0.21 mmol), 14e (79 mg, $0.32 \mathrm{mmol})$ and $4 \AA$ molecular sieves in toluene $(0.8 \mathrm{~mL})$. The resulting residue was purified by CCTLC (hexane/ethyl acetate, 2:1) to afford $73 \mathrm{mg}(76 \%)$ of $16 \mathrm{e}$ as a white solid. Mp 65-67 ${ }^{\circ} \mathrm{C}{ }^{1} \mathrm{H}$ NMR (DMSO- $d_{6}, 400 \mathrm{MHz}$ ): $\delta 2.48$ (s, 3H, $\mathrm{CH}_{3}$ ), 2.53-2.62 (m, 2H, H-4, H-6), 2.71-2.88 (m, 2H, H-4, H-6), 3.29 (m, 1H, H-5), 3.72 (s, 3H, OCH ) $_{3} 3.74$ (s, $\left.3 \mathrm{H}, \mathrm{OCH}_{3}\right), 6.52(\mathrm{dd}, J=8.7,2.8 \mathrm{~Hz}, 1 \mathrm{H}, \mathrm{Ar}), 6.76(\mathrm{~d}, J=2.8 \mathrm{~Hz}, 1 \mathrm{H}, \mathrm{Ar}), 6.90-6.96(\mathrm{~m}, 2 \mathrm{H}$, Ar), 7.15-7.28 (m, 2H, Ar), 7.28-7.40 (m, 5H, Ar), 7.45 (dd, $J=7.9,1.6 \mathrm{~Hz}, 1 \mathrm{H}, \mathrm{Ar}$ ), 14.89 (br s, $1 \mathrm{H}, \mathrm{NH}) .{ }^{13} \mathrm{C}$ NMR (DMSO- $\left.d_{6}, 100 \mathrm{MHz}\right): \delta 20.0\left(\mathrm{CH}_{3}\right), 36.1(\mathrm{C}-5), 45.2(\mathrm{C}-4, \mathrm{C}-6), 55.7$ $\left(\mathrm{OCH}_{3}\right), 55.9\left(\mathrm{OCH}_{3}\right), 104.7(\mathrm{Ar}), 108.5(\mathrm{NHC}=\underline{\mathrm{C}}), 110.4,112.5,117.8,123.2,126.3,126.5$, 126.7, 127.8, 128.5, 129.3, 143.5, 145.7, 149.00, 149.8, $152.0(\mathrm{Ar}), 172.7(\mathrm{NH} \underline{\mathrm{C}}=\mathrm{C}) . \mathrm{MS}(\mathrm{ES}$, positive mode): $458(\mathrm{M}+\mathrm{H})^{+}, 915(2 \mathrm{M}+\mathrm{H})^{+}$. Anal. calc. for $\left(\mathrm{C}_{28} \mathrm{H}_{27} \mathrm{NO}_{5}\right): \mathrm{C}, 73.51 ; \mathrm{H}, 5.95 ; \mathrm{N}$, 3.06. Found: C, 73.32; H, 6.00; N, 3.24.

4.1.3.6.

tert-Butyl

(3-(2-)(1-(2,6-dioxo-4-

phenylcyclohexylidene)ethyl)amino)phenoxy)phenyl)carbamate (16f) 
Following the general procedure $\mathrm{C}$, an Ace pressure tube was charged with 15 (110 mg, 0.48 mmol), $14 f(215 \mathrm{mg}, 0.72 \mathrm{mmol})$ and $4 \AA$ molecular sieves in toluene $(2 \mathrm{~mL})$. The resulting residue was purified by CCTLC (hexane/ethyl acetate, 2:1) to afford $153 \mathrm{mg}(71 \%)$ of $\mathbf{1 6 f}$ as a white solid. Mp 159-161 ${ }^{\circ} \mathrm{C} .{ }^{1} \mathrm{H}$ NMR (DMSO- $\left.d_{6}, 400 \mathrm{MHz}\right): \delta 1.43\left(\mathrm{~s}, 9 \mathrm{H},\left(\mathrm{CH}_{3}\right)_{3}\right), 2.44$ (s, $3 \mathrm{H}, \mathrm{CH}_{3}$ ), 2.52-2.64 (m, 2H, H-4, H-6), 2.68-2.84 (m, 2H, H-4, H-6), 3.27 (tt, $J=12.2,4.0 \mathrm{~Hz}$, 1H, H-5), 6.54 (m, 1H, Ar), 7.08 (dd, J=8.2, 1.3 Hz, 1H, Ar), 7.15-7.25 (m, 4H, Ar), 7.28 (m, 1H, Ar), 7.28-7.37 (m, 4H, Ar), 7.41 (m, 1H, Ar), 7.49 (dd, J=7.8, 1.6 Hz, 1H, Ar), 9.46 (br s, $1 \mathrm{H}, \mathrm{CONH}$ ), 14.85 (br s, $1 \mathrm{H}, \mathrm{NH}) .{ }^{13} \mathrm{C}$ NMR (DMSO-d $6,100 \mathrm{MHz}$ ): $\delta 19.8\left(\mathrm{CH}_{3}\right), 28.0$ $\left(\left(\mathrm{CH}_{3}\right)_{3}\right), 36.0(\mathrm{C}-5), 46.3(\mathrm{C}-4, \mathrm{C}-6), 79.3\left(\underline{\mathrm{C}}\left(\mathrm{CH}_{3}\right)_{3}\right), 108.5(\mathrm{NHC}=\underline{\mathrm{C}}), 107.7$ 111.5, 113.4, $119.8,124.3,126.5,126.7,127.5,128.0,128.5,129.4,130.0,141.2,143.5,150.6,152.6$ $(\mathrm{CONH}), 156.4(\mathrm{Ar}), 172.5(\mathrm{NH} \underline{\mathrm{C}}=\mathrm{C})$. MS (ES, positive mode): $513(\mathrm{M}+\mathrm{H})^{+}$. Anal. calc. for $\left(\mathrm{C}_{31} \mathrm{H}_{32} \mathrm{~N}_{2} \mathrm{O}_{5}\right)$ : C, 72.64; H, 6.29; N, 5.47. Found: C, 72.52; H, 6.34; N, 5.74.

4.1.3.7. tert-Butyl (4-(2-((1-)(2,6-dioxo-4phenylcyclohexylidene)ethyl)amino)phenoxy)phenyl)carbamate (16g)

Following the general procedure $C$, an Ace pressure tube was charged with 15 (100 mg, 0.43 mmol), 14g (195 mg, $0.65 \mathrm{mmol})$ and $4 \AA$ molecular sieves in toluene $(1.9 \mathrm{~mL})$. The resulting residue was purified by CCTLC (hexane/ethyl acetate, 2:1) to afford $192 \mathrm{mg}(87 \%)$ of $\mathbf{1 6 g}$ as a white solid. Mp 108-110 ${ }^{\circ} \mathrm{C} .{ }^{1} \mathrm{H}$ NMR (DMSO- $\left.d_{6}, 400 \mathrm{MHz}\right): \delta 1.46\left(\mathrm{~s}, 9 \mathrm{H},\left(\mathrm{CH}_{3}\right)_{3}\right), 2.46(\mathrm{~s}$, $3 \mathrm{H}, \mathrm{CH}_{3}$ ), 2.53-2.56 (m, 2H, H-4, H-6), 2.68-2.87 (m, 2H, H-4, H-6), 3.28 (m, 1H, H-5), 6.916.96 (m, 3H, Ar), $7.18-7.25$ (m, 2H, Ar), 7.30-7.34 (m, 4H, Ar), 7.36 (ddd, $J=8.3,7.5,1.7$ $\mathrm{Hz}, 1 \mathrm{H}, \mathrm{Ar}), 7.44-7.48$ (m, 3H, Ar), 9.38 (br s, $1 \mathrm{H}, \mathrm{CONH}), 14.88$ (br s, $1 \mathrm{H}, \mathrm{NH}) .{ }^{13} \mathrm{C} \mathrm{NMR}$ (DMSO- $\left.d_{6}, 100 \mathrm{MHz}\right): \delta 19.9\left(\mathrm{CH}_{3}\right), 28.1\left(\left(\mathrm{CH}_{3}\right)_{3}\right), 36.0(\mathrm{C}-5), 45.9(\mathrm{C}-4, \mathrm{C}-6), 79.0\left(\underline{\mathrm{C}}\left(\mathrm{CH}_{3}\right)_{3}\right)$, $108.6(\mathrm{NHC}=\underline{\mathrm{C}}), 118.2,119.4,119.7,123.4,126.5,126.6,126.7,127.9,128.5,129.3,136.0$, 143.5, 150.0, $151.6(\mathrm{Ar}), 152.8(\mathrm{CONH}), 172.5(\mathrm{NH} \underline{\mathrm{C}}=\mathrm{C}) . \mathrm{MS}$ (ES, positive mode): 513 $(\mathrm{M}+\mathrm{H})^{+}$. Anal. calc. for $\left(\mathrm{C}_{31} \mathrm{H}_{32} \mathrm{~N}_{2} \mathrm{O}_{5}\right): \mathrm{C}, 72.64 ; \mathrm{H}, 6.29 ; \mathrm{N}, 5.47$. Found: $\mathrm{C}, 72.29 ; \mathrm{H}, 6.39 ; \mathrm{N}$, 5.65 .

4.1 .3 .8

tert-Butyl

(4-(2-)(1-(2,6-dioxo-4-

phenylcyclohexylidene)ethyl)amino)phenoxy)methoxyphenyl)carbamate (16h)

Following the general procedure $\mathrm{C}$, an Ace pressure tube was charged with 15 (65 mg, 0.28 mmol), 14h (62 mg, $0.19 \mathrm{mmol})$ and $4 \AA$ molecular sieves in toluene $(0.8 \mathrm{~mL})$. The resulting residue was purified by CCTLC (hexane/ethyl acetate, 3:1) to afford $78 \mathrm{mg}$ (76\%) of 16has a white solid. Mp 189-191 ${ }^{\circ} \mathrm{C} .{ }^{1} \mathrm{H}$ NMR (DMSO- $\left.d_{6}, 400 \mathrm{MHz}\right): \delta 1.44\left(\mathrm{~s}, 9 \mathrm{H},\left(\mathrm{CH}_{3}\right)_{3}\right), 2.47$ (s, $3 \mathrm{H}, \mathrm{CH}_{3}$ ), 2.53-2.66 (m, 2H, H-4, H-6), $2.69-2.91$ (m, 2H, H-4, H-6), 3.28 (m, 1H, H-5), 3.76 (s, $\left.3 \mathrm{H}, \mathrm{OCH}_{3}\right), 6.49$ (dd, $\left.J=8.7,2.6 \mathrm{~Hz}, 1 \mathrm{H}, \mathrm{Ar}\right), 6.76$ (d, $\left.J=2.6 \mathrm{~Hz}, 1 \mathrm{H}, \mathrm{Ar}\right), 7.00$ (dd, $J=8.2$, $1.3 \mathrm{~Hz}, 1 \mathrm{H}, \mathrm{Ar}), 7.20-7.26$ (m, 2H, Ar), 7.32 (m, 4H, Ar), 7.38 (m, 1H, Ar), 7.47 (dd, J = 7.9, $1.6 \mathrm{~Hz}, 1 \mathrm{H}, \mathrm{Ar}), 7.57$ (d, $J=8.7 \mathrm{~Hz}, 1 \mathrm{H}, \mathrm{Ar}), 7.99$ (br s, $1 \mathrm{H}, \mathrm{CONH}), 14.89$ (br s, $1 \mathrm{H}, \mathrm{NH}) .{ }^{13} \mathrm{C}$ 
NMR (DMSO-d $\left.d_{6}, 100 \mathrm{MHz}\right): \delta 19.9\left(\mathrm{CH}_{3}\right), 28.1\left(\left(\mathrm{CH}_{3}\right)_{3}\right), 36.1(\mathrm{C}-5), 45.5(\mathrm{C}-4, \mathrm{C}-6), 55.9$ $\left(\mathrm{OCH}_{3}\right), 79.1\left(\underline{\mathrm{C}}\left(\mathrm{CH}_{3}\right)_{3}\right), 103.3(\mathrm{Ar}), 108.6(\mathrm{NHC}=\underline{\mathrm{C}}), 109.9,118.6,122.6,123.7,126.5,126.8$, 128.0, 128.5, 129.4, 143.5, $151.3(\mathrm{Ar}), 151.9(\mathrm{CONH}), 153.0(\mathrm{Ar}), 172.6(\mathrm{NH} \underline{\mathrm{C}}=\mathrm{C})$. MS (ES, positive mode): $543(\mathrm{M}+\mathrm{H})^{+}$. Anal. calc. for $\left(\mathrm{C}_{32} \mathrm{H}_{34} \mathrm{~N}_{2} \mathrm{O}_{6}\right)$ : C, 70.83; H, 6.32; N, 5.16. Found: C, 70.60; H, 6.33; N, 5.37.

4.1.3.9. 2-(1-((2-(4-Acetylphenoxy)phenyl)amino)ethylidene)-5-phenylcyclohexane-1,3-dione (16i)

Following the general procedure $C$, an Ace pressure tube was charged with 15 (26 mg, 0.11 mmol), $14 \mathbf{i}(39 \mathrm{mg}, 0.17 \mathrm{mmol})$ and $4 \AA$ molecular sieves in toluene $(0.5 \mathrm{~mL})$. The resulting residue was purified by CCTLC (hexane/ethyl acetate, 1:1) to afford $24 \mathrm{mg}(48 \%)$ of $\mathbf{1 6 i}$ as a white solid. Mp 103-105 ${ }^{\circ} \mathrm{C} .{ }^{1} \mathrm{H}$ NMR (DMSO- $d_{6}, 400 \mathrm{MHz}$ ): $\delta 2.45$ (s, 3H, $\mathrm{CH}_{3}$ ), $2.54(\mathrm{~s}, 3 \mathrm{H}$, $\mathrm{COCH}_{3}$ ), 2.52-2.58 (m, 2H, H-4, H-6), 2.67-2.81 (m, 2H, H-4, H-6), 3.23 (tt, J=12.0, 4.0 Hz, 1H, H-5), 7.01-7.06 (m, 2H, Ar), 7.20-7.34 (m, 6H, Ar), 7.37 (td, J= 7.7, 1.4 Hz, 1H, Ar), 7.48 (td, $J=7.8,1.7 \mathrm{~Hz}, 1 \mathrm{H}, \mathrm{Ar}), 7.55$ (dd, $J=7.9,1.7 \mathrm{~Hz}, 1 \mathrm{H}, \mathrm{Ar}), 7.95-7.99$ (m, 2H, Ar), 14.85 (br s, $1 \mathrm{H}, \mathrm{NH}) .{ }^{13} \mathrm{C}$ NMR (DMSO- $\left.d_{6}, 100 \mathrm{MHz}\right): \delta 19.8\left(\mathrm{CH}_{3}\right), 26.6\left(\mathrm{COCH}_{3}\right), 36.0(\mathrm{C}-5), 45.0(\mathrm{C}-$ 4, C-6), $108.6(\mathrm{NHC}=\underline{\mathrm{C}}), 117.1,121.2,125.6,126.5,126.7,128.3,128.3,128.5,129.7,130.8$, 132.3, 143.4, 149.2, 160.4, $172.4(\mathrm{NHC}=\mathrm{C}), 196.5\left(\mathrm{COCH}_{3}\right) . \mathrm{MS}$ (ES, positive mode): 440 $(\mathrm{M}+\mathrm{H})^{+}$. Anal. calc. for $\left(\mathrm{C}_{28} \mathrm{H}_{25} \mathrm{NO}_{4}\right)$ : C, 76.52; H, 5.73; N, 3.19. Found: C, 76.12; H, 5.87; N, 3.24 .

4.1.3.10. 2-(1-((2-(4-(1-Hydroxyethyl)phenoxy)phenyl)amino)ethylidene)-5-phenylcyclohexane1,3-dione (16j)

Following the general procedure $\mathrm{C}$, an Ace pressure tube was charged with 15 (30 mg, 0.14 mmol), 14j (46 mg, $0.20 \mathrm{mmol})$ and $4 \AA$ molecular sieves in toluene $(1 \mathrm{~mL})$. The resulting residue was purified by CCTLC (hexane/ethyl acetate, $1 ; 1)$ to afford $16 \mathrm{mg}(28 \%)$ of $\mathbf{1 6} \mathbf{j}$ as a white solid. Mp 60-62 ${ }^{\circ} \mathrm{C} .{ }^{1} \mathrm{H}$ NMR (DMSO- $\left.d_{6}, 500 \mathrm{MHz}\right): \delta 1.31(\mathrm{~d}, J=6.4 \mathrm{~Hz}, 3 \mathrm{H}$, $\left(\mathrm{CH}_{3}\right) \mathrm{CHOH}$ ), 2.46 (s, 3H, $\left.\mathrm{CH}_{3}\right), 2.54-2.61$ (m, 2H, H-4, H-6), 2.70-2.84 (m, 2H, H-4, H-6), 3.28 (m, 1H, H-5), 4.71 (qd, $J=6.3,4.1 \mathrm{~Hz}, 1 \mathrm{H}, \mathrm{C} \underline{\mathrm{HOH}}$ ), 5.16 (d, $J=4.2 \mathrm{~Hz}, 1 \mathrm{H}, \mathrm{OH}), 6.93-$ 6.97 (m, 2H, Ar), 7.00 (dd, $J=8.2,1.3 \mathrm{~Hz}, 1 \mathrm{H}, \mathrm{Ar}$ ), 7.20-7.27 (m, 2H, Ar), 7.28-7.33 (m, 4H, Ar), 7.34-7.37 (m, 2H, Ar), 7.39 (td, $J=7.8,1.7 \mathrm{~Hz}, 1 \mathrm{H}, \mathrm{Ar}), 7.48$ (dd, $J=7.9,1.6 \mathrm{~Hz}, 1 \mathrm{H}, \mathrm{Ar})$, 14.90 (br s, $1 \mathrm{H}, \mathrm{NH}) .{ }^{13} \mathrm{C}$ NMR (DMSO- $\left.d_{6}, 125 \mathrm{MHz}\right): \delta 19.9\left(\mathrm{CH}_{3}\right), 26.0\left(\left(\underline{\mathrm{CH}}_{3} \mathrm{CHOH}\right), 36.0\right.$ (C-5), $45.3(\mathrm{C}-4, \mathrm{C}-6), 67.5(\mathrm{CHOH}), 108.6(\mathrm{NHC}=\underline{\mathrm{C}}), 118.2,119.0,123.9,126.5,126.3,127.0$, 127.1, 127.9, 128.5, 129.4, 143.2, 143.5, 151.1, $154.4(\mathrm{Ar}), 172.5(\mathrm{NHC}=\mathrm{C})$. MS (ES, positive mode): $442(\mathrm{M}+\mathrm{H})^{+}$. Analytical HPLC (gradient 15-95\% acetonitrile in $10 \mathrm{~min}$ ): $\mathrm{T}_{\mathrm{R}}: 6.08$; area: $100 \%$. (gradient $50-70 \%$ acetonitrile in $10 \mathrm{~min}$ ): $\mathrm{T}_{\mathrm{R}}: 4.57$; area: $100 \%$.

4.1.3.11. 2-(1-((2-Phenoxyphenyl)amino)ethylidene)-5-phenylcyclohexane-1,3-dione (16k) 
Following the general procedure $C$, an Ace pressure tube was charged with 15 (58 mg, 0.26 mmol), 2-phenoxyaniline (14k) (73 mg, $0.39 \mathrm{mmol})$ and $4 \AA$ molecular sieves in toluene (1.1 $\mathrm{mL}$ ). The resulting residue was purified by CCTLC (hexane/ethyl acetate, 2:1) to afford $70 \mathrm{mg}$ $(68 \%)$ of $16 k$ as an oil. ${ }^{1} \mathrm{H}$ NMR (DMSO- $\left.d_{6}, 400 \mathrm{MHz}\right): \delta 2.46$ (s, 3H, $\left.\mathrm{CH}_{3}\right), 2.53-2.62(\mathrm{~m}, 2 \mathrm{H}$, H-4, H-6), 2.66-2.87 (m, 2H, H-4, H-6), 3.28 (m, 1H, H-5), 6.98-7.05 (m, 3H, Ar), 7.14-7.25 (m, 2H, Ar), 7.28 (dd, J=7.6, 1.4 Hz, 1H, Ar), 7.30-7.38 (m, 5H, Ar), 7.40-7.44 (m, 2H, Ar), 7.49 (dd, $J=7.9,1.7 \mathrm{~Hz}, 1 \mathrm{H}, \mathrm{Ar}), 14.89$ (br s, $1 \mathrm{H}, \mathrm{NH}) .{ }^{13} \mathrm{C}$ NMR (DMSO- $d_{6}, 100 \mathrm{MHz}$ ): $\delta 19.8$ $\left(\mathrm{CH}_{3}\right), 36.0(\mathrm{C}-5), 45.8$ (C-4, C-6), $108.6(\mathrm{HNC}=\underline{\mathrm{C}}), 118.4,119.3,124.0,124.1,126.5,126.7$, 127.3, 128.0, 128.5, 129.4, 130.2, 143.4, 150.8, 156.0 (Ar), $172.5(\mathrm{HNC}=\mathrm{C})$. MS (ES, positive mode): $398(\mathrm{M}+\mathrm{H})^{+}$.Anal. calc. for $\left(\mathrm{C}_{26} \mathrm{H}_{30} \mathrm{~N}_{2} \mathrm{O}_{4}\right): \mathrm{C}, 78.59 ; \mathrm{H}, 5.83 ; \mathrm{N}, 3.52$. Found: $\mathrm{C}, 78.30$; $\mathrm{H}, 5.95 ; \mathrm{N}, 3.58$.

4.1.3.12. 2-(1-((2-(3-Aminophenoxy)phenyl)amino)ethylidene)-5-phenylcyclohexane-1,3-dione (16)

To a solution of $\mathbf{1 6 f}(60 \mathrm{mg}, 0.12 \mathrm{mmol})$ in dichloromethane $(0.4 \mathrm{~mL})$, TFA $(0.4 \mathrm{~mL}, 4.68$ mmol) was added and the reaction mixture was stirred at room temperature for $30 \mathrm{~min}$. Then volatiles were removed and the residue was purified by CCTLC (hexane/ethyl acetate, 1:1) to afford $47 \mathrm{mg}$ (97\%) of $\mathbf{1 6 1}$ as a white solid. Mp 76-78 ${ }^{\circ} \mathrm{C} .{ }^{1} \mathrm{H}$ NMR (DMSO- $d_{6}, 400 \mathrm{MHz}$ ): $\delta$ 2.46 (s, 3H, $\mathrm{CH}_{3}$ ), 2.53-2.63 (m, 2H, H-4, H-6), 2.68-2.88 (m, 2H, H-4, H-6), 3.30 (m, 1H, H5), 5.27 (br s, 2H, $\mathrm{NH}_{2}$ ), 6.08 (ddd, $J=8.0,2.4,0.9 \mathrm{~Hz}, 1 \mathrm{H}, \mathrm{Ar}$ ), 6.16 (t, $J=2.2 \mathrm{~Hz}, 1 \mathrm{H}, \mathrm{Ar}$ ), 6.34 (ddd, $J=8.1,2.2,0.9 \mathrm{~Hz}, 1 \mathrm{H}, \mathrm{Ar}), 6.98$ (t, $J=8.0 \mathrm{~Hz}, 1 \mathrm{H}, \mathrm{Ar}$ ), 7.04 (dd, $J=8.3,1.3 \mathrm{~Hz}$, 1H, Ar), 7.17-7.25 (m, 2H, Ar), 7.30-7.33 (m, 4H, Ar), 7.38 (td, J = 7.8, 1.6 Hz, 1H, Ar), 7.45 (dd, $J=7.9,1.6 \mathrm{~Hz}, 1 \mathrm{H}, \mathrm{Ar}), 14.87$ (br s, $1 \mathrm{H}, \mathrm{NH}) .{ }^{13} \mathrm{C}$ NMR (DMSO-d $d_{6}, 100 \mathrm{MHz}$ ): $\delta 19.8$ $\left(\mathrm{CH}_{3}\right), 36.0$ (C-5), 45.3 (C-4, C-6), 103.4, 105.4 (Ar), 108.5 (NHC=) , 109.7, 119.4, 123.7, $126.5,126.7,127.2,127.8,128.5,129.3,130.1,143.5,150.6,151.0,156.9$ (Ar), 172.5 $(\mathrm{NH} \underline{\mathrm{C}}=\mathrm{C})$. MS (ES, positive mode): $413(\mathrm{M}+\mathrm{H})^{+}$. Anal. calc. for $\left(\mathrm{C}_{26} \mathrm{H}_{24} \mathrm{~N}_{2} \mathrm{O}_{3} \cdot \mathrm{H}_{2} \mathrm{O}\right): \mathrm{C}, 72.54$; H, 6.09; N, 6.51. Found: C, 72.86; H, 5.84; N, 6.89.

4.1.3.13. 4-(2-((1-(2,6-Dioxo-4-phenylcyclohexylidene)ethyl)amino)phenoxy)benzen-aminium 2,2,2-trifluoroacetate $(\mathbf{1 6 m})$

To a solution of $\mathbf{1 6 g}(66 \mathrm{mg}, 0.13 \mathrm{mmol})$ in dichloromethane $(0.4 \mathrm{~mL})$, TFA $(0.4 \mathrm{~mL}, 5.07$ mmol) was added and the reaction mixture was stirred at room temperature for $20 \mathrm{~min}$. Then volatiles were removed and the residue was triturated with dichloromethane and hexane yielding $65 \mathrm{mg}(99 \%)$ of $\mathbf{1 6 m}$ as a white solid. Mp 73-75 ${ }^{\circ} \mathrm{C}$. ${ }^{1} \mathrm{H}$ NMR (DMSO- $d_{6}, 400 \mathrm{MHz}$ ): $\delta 2.46$ (s, $3 \mathrm{H}, \mathrm{CH}_{3}$ ), 2.54-2.61 (m, 2H, H-4, H-6), 2.69-2.86 (m, 2H, H-4, H-6), 3.29 (tt, J= 12.1, 4.0 Hz, 1H, H-5), 7.00-7.07 (m, 3H, Ar), 7.15-7.20 (m, 2H, Ar), 7.20-7.36 (m, 6H, Ar), 7.41 (ddd, $J=$ 8.3, 7.3, $1.7 \mathrm{~Hz}, 1 \mathrm{H}, \mathrm{Ar}), 7.50$ (dd, $J=7.9,1.6 \mathrm{~Hz}, 1 \mathrm{H}, \mathrm{Ar}), 14.89$ (br s, $1 \mathrm{H}, \mathrm{NH}) .{ }^{13} \mathrm{C} \mathrm{NMR}$ (DMSO- $\left.d_{6}, 100 \mathrm{MHz}\right): \delta 19.9\left(\mathrm{CH}_{3}\right), 36.0(\mathrm{C}-5), 45.9(\mathrm{C}-4, \mathrm{C}-6), 108.6(\mathrm{NHC}=\underline{\mathrm{C}}), 119.1,119.6$, 
$122.3,124.2,126.6,126.7,127.2,128.0,128.5,129.5,132.2,143.4,150.8,152.8(\operatorname{Ar}), 158.2(\mathrm{q}$,

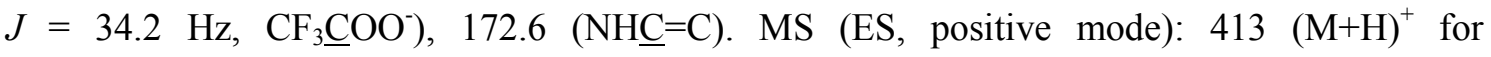
$\mathrm{C}_{26} \mathrm{H}_{24} \mathrm{~N}_{2} \mathrm{O}_{3}$. Anal. calc. for $\left(\mathrm{C}_{28} \mathrm{H}_{25} \mathrm{~F}_{3} \mathrm{~N}_{2} \mathrm{O}_{5} \cdot \mathrm{H}_{2} \mathrm{O}\right)$ : C, 63.87; H, 4.79; N, 5.32. Found: $\mathrm{C}, 63.50$; $\mathrm{H}, 4.74 ; \mathrm{N}, 5.14$.

4.1.3.14. 4-(2-((1-(2,6-Dioxo-4-phenylcyclohexylidene)ethyl)amino)phenoxy)-2methoxybenzenaminium 2,2,2-trifluoroacetate (16n)

To a solution of $\mathbf{1 6 h}(20 \mathrm{mg}, 0.04 \mathrm{mmol})$ in dichloromethane $(0.5 \mathrm{~mL})$, TFA $(0.1 \mathrm{~mL}, 1.47$ mmol) was added and the reaction mixture was stirred at room temperature for $1 \mathrm{~h}$. Then volatiles were removed and the residue was triturated with dichloromethane and hexane yielding $18 \mathrm{mg}(88 \%)$ of $\mathbf{1 6 n}$ as a white solid. Mp 79-81 ${ }^{\circ} \mathrm{C} .{ }^{1} \mathrm{H}$ NMR (DMSO- $d_{6}, 400 \mathrm{MHz}$ ): $\delta 2.48$ (s, $3 \mathrm{H}, \mathrm{CH}_{3}$ ), 2.55-2.63 (m, 2H, H-4, H-6), 2.71-2.85 (m, 2H, H-4, H-6), 3.30 (tt, J= 12.1, $4.0 \mathrm{~Hz}$, 1H, H-5), 3.82 (s, 3H, OCH $), 6.50$ (dd, $J=8.5,2.5 \mathrm{~Hz}, 1 \mathrm{H}, \mathrm{Ar}), 6.83$ (d, $J=2.5 \mathrm{~Hz}, 1 \mathrm{H}, \mathrm{Ar}$ ), 7.00 (dd, $J=8.3,1.3 \mathrm{~Hz}, 1 \mathrm{H}, \mathrm{Ar}), 7.04$ (d, $J=8.5 \mathrm{~Hz}, 1 \mathrm{H}, \mathrm{Ar}$ ), 7.20-7.26 (m, 2H, Ar), 7.307.34 (m, 4H, Ar), 7.39 (ddd, $J=8.2,7.4,1.7 \mathrm{~Hz}, 1 \mathrm{H}, \mathrm{Ar}$ ), 7.48 (dd, $J=7.9,1.6 \mathrm{~Hz}, 1 \mathrm{H}, \mathrm{Ar}$ ), 14.88 (br s, $1 \mathrm{H}, \mathrm{NH}) .{ }^{13} \mathrm{C}$ NMR (DMSO-d, $100 \mathrm{MHz}$ ): $\delta 19.9\left(\mathrm{CH}_{3}\right), 36.1$ (C-5), $45.4(\mathrm{C}-4, \mathrm{C}-$ 6), $56.1\left(\mathrm{OCH}_{3}\right), 108.6(\mathrm{NHC}=\mathrm{C}), 103.8,110.6,118.5,120.3,123.8,126.6,126.8,128.0,128.5$, 129.4, 143.4, 150.9, $151.3(\mathrm{Ar}), 172.6(\mathrm{NHC}=\underline{\mathrm{C}})$. MS (ES, positive mode): $443(\mathrm{M}+\mathrm{H})^{+}$for $\mathrm{C}_{27} \mathrm{H}_{26} \mathrm{~N}_{2} \mathrm{O}_{4}$. Anal. calc. for $\left(\mathrm{C}_{29} \mathrm{H}_{27} \mathrm{~F}_{3} \mathrm{~N}_{2} \mathrm{O}_{6}\right)$ : C, 62.59; H, 4.89; N, 5.03. Found: $\mathrm{C}, 62.22 ; \mathrm{H}$, $5.10 ; \mathrm{N}, 5.21$.

\subsection{Biological Methods}

The human microvascular endothelial cell line HMEC-1 was obtained from the Centers for Disease Control and Prevention (Atlanta, GA, USA) and used from passage 17 till 27. Human cervical carcinoma (HeLa) and human T-lymphoid (CEM) cells were obtained from ATCC (Middlesex, UK). Cell lines were maintained in culture for up to 3 months and grown in DMEM, supplemented with $10 \% \mathrm{FBS}, 0.01 \mathrm{M}$ Hepes and $1 \mathrm{mM}$ sodium pyruvate. All cells were cultured in a humidified $5 \% \mathrm{CO}_{2}$ incubator at $37^{\circ} \mathrm{C}$.

\subsubsection{Cell proliferation}

HMEC-1 cells were seeded in 48-well plates at 20,000 cells/well. After 24 h, 5-fold dilutions of the compounds were added. The cells were allowed to proliferate 4 days in the presence of the compounds, trypsinized, and counted by means of a Coulter counter (Analis, Belgium). Human cervical carcinoma (HeLa) cells were seeded in 48 -well plates at 10,000 cells/well. After 24h, different concentrations of the compounds were added. After 3 days of incubation, the cells were trypsinized and counted in a Coulter counter. Suspension cells (Mouse leukemia L1210 and human lymphoid CEM cells) were seeded in 96-well plates at 60,000 cells/well in the presence of different concentrations of the compounds, allowed to proliferate for $96 \mathrm{~h}$, and 
counted in a Coulter counter. The $50 \%$ inhibitory concentration $\left(\mathrm{IC}_{50}\right)$ was defined as the compound concentration required to reduce cell proliferation by $50 \%$.

\subsubsection{Cell cycle analysis}

HMEC-1 cells were seeded in 6-well plates at 125,000 cells/well in DMEM with $10 \%$ FBS. After $24 \mathrm{~h}$, the cells were exposed to different concentrations of the compounds. After $24 \mathrm{~h}$, the DNA of the cells was stained with propidium iodide using the CycleTEST PLUS DNA Reagent Kit (BD Biosciences, San Jose, CA). The DNA content of the stained cells was assessed by flow cytometry on a FACSCalibur flow cytometer and analyzed with CellQuest software (BD Biosciences) within $3 \mathrm{~h}$ after staining. Cell debris and clumps were excluded from the analysis by appropriate dot plot gating. Percentages of sub-G1, G1, S, and $\mathrm{G}_{2} / \mathrm{M}$ cells were estimated using appropriate region markers [33].

\subsubsection{Tube formation}

Wells of a 96-well plate were coated with $70 \mu 1$ matrigel $(10 \mathrm{mg} / \mathrm{ml}$, BD Biosciences, Heidelberg, Germany) at $4^{\circ} \mathrm{C}$. After gelatinization at $37^{\circ} \mathrm{C}$ during $30 \mathrm{~min}$, HMEC-1 cells were seeded at 60,000 cells/well on top of the matrigel in $200 \mu 1$ DMEM containing $10 \%$ FCS. After $3 \mathrm{~h}$ of incubation at $37^{\circ} \mathrm{C}$, when the endothelial cells had reorganized to form tube-like structures, the compounds were added. Ninety minutes later, the cultures were photographed at $100 \mathrm{x}$ magnification and analyzed using digitalized analysis.

\subsubsection{Determination of binding constants}

Proteins and ligands. Calf brain tubulin was purified as described [34]. $(R)-(+)$-ethyl 5-amino 2methyl-1,2-dihydro-3-phenylpyrido[3,4-b]pyrazin-7-yl carbamate (R-PT)[35] was a kind gift of Prof. G.A. Rener, Organic Chemistry Research Department, Southern Research Institute, Birminghm, Alabama. The compounds were diluted in 99.8\% D6-DMSO (Merck, Darmstadt, Germany) to a final concentration of $20 \mathrm{mM}$ and stored at $-80^{\circ} \mathrm{C}$.

Determination of binding constants. The binding constant of R-PT [25] for dimeric tubulin was determined using the competition method in $10 \mathrm{mM}$ sodium phosphate, $0.1 \mathrm{mM}$ GTP pH 7.0 at $25^{\circ} \mathrm{C}$. To do so $0.2 \mu \mathrm{M}$ of R-PT was incubated with increasing amounts of tubulin up to $10 \mu \mathrm{M}$ and vice versa, $0.2 \mu \mathrm{M}$ of tubulin was incubated with increasing amounts of R-PT up to $10 \mu \mathrm{M}$, the fluorescence emission spectra (excitation $374 \mathrm{~nm}$ ) of the samples (5 nm excitation and emission slits) were determined using a Jobin-Ybon SPEX Fluoromax-2 (HORIBA, Ltd. Kyoto, Japan). Using these spectra it is possible to calculate the free and the bound R-PT concentration for each sample and thus to determine the binding constant of R-PT for tubulin.

Once $\mathrm{K}_{\mathrm{b}}$ of R-PT is determined $\left(5.1 \times 10^{6} \mathrm{M}^{-1}\right)$ this compound could be used as a reference ligand as described in ref. [36]. For that purpose, the fluorescence emission of a previous mixed sample of $0.2 \mu \mathrm{M}$ of R-PT and $0.2 \mu \mathrm{M}$ of tubulin was evaluated in the presence of increasing concentrations of the studied ligand in a black 96 -well plate $(0 ; 0.05 ; 0.2 ; 0.5 ; 2 ; 5 ; 10 ; 30 ; 50$; $70 \mu \mathrm{M}$ ). The samples were incubated $30 \mathrm{~min}$. at $25^{\circ} \mathrm{C}$ in a Varioskan plate reader (Thermo 
Scientific Waltham, Massachusetts, USA) before the fluorescence emission intensity at $456 \mathrm{~nm}$ (excitation $374 \mathrm{~nm}$ ) was measured. The data were analyzed and the binding constants determined using Equigra V5.0 [37].

\subsubsection{Tubulin assembly time-course}

Tubulin was diluted at a final concentration of $25 \mathrm{uM}$ in a $10 \mathrm{mM} \mathrm{NaPi}, 1 \mathrm{mM}$ EGTA, $1 \mathrm{mM}$ GTP $(\mathrm{pH}=7)$ buffer supplemented with $3.4 \mathrm{M}$ glycerol. Each polymerization reaction was prepared in a 96-well plate to a final volume of $100 \mathrm{uL}$ with $30 \mathrm{uM}$ of each of the compounds tested (or the equivalent volume of DMSO for the control). Polymerization was followed throughout time measuring the scattering of light $(\lambda=350 \mathrm{~nm})$ using a Varioskan plate reader (Thermo Scientific Waltham, Massachusetts, USA)

\subsection{Computational methods.}

\subsubsection{Affinity maps calculation}

Binding pocket analysis of the tubulin-DAMA-colchicine was carried out with cGRILL [17, 18], a computational tools formally equivalent to Goodford's program GRID [38]. Hydrogen atoms, atom point charges and radii for all atoms in the complexes were calculated by submission to $\mathrm{H}++$ server (http://biophysics.cs.vt.edu) in order to obtain their pqr format files. Grid center was defined by selecting the corresponding ligand and a cubic box of 50x50x50 points and a $0.5 \AA$ was set for the calculations. cGRILL evaluates, at each grid point, the interaction energy between the whole receptor and five different probes combining van der Waals (Leonard-jones potential), electrostatic (Coulombic), and hydrogen bonding[39] (geometry based) terms.

The five calculated affinity maps: lipophilic $(\mathrm{CH} 3)$, hydrogen bond acceptor $(=\mathrm{O})$, hydrogen bond donor $\left(\mathrm{NH}^{+}\right)$, mixed hydrogen bond donor-aceptor $(\mathrm{OH})$ and hydrophobic-like (hydrophobic) were visualized and analysed using the PyMOL plugin provided with the software.

\subsubsection{Docking of $\mathbf{1 6 n}$}

Compound 16n was used as ligand for the automated docking experiments using TUB075 tubulin complex (PDB ID: 6KFJ)[16]. AMBER-compatible RESP point charges were used for 16n. The Lamarkian genetic algorithm implemented in AutoDock 4.2[40] was used to generate the docked conformations within the putative binding cavity by randomly changing the overall orientation of the molecule as well as the torsion angles of all rotable bonds. Default settings were used except for the number of runs, population size, and maximum number of energy evaluations, which were fixed at 250, 100 and 250.000, respectively. Rapid intra- and intermolecular energy evaluations of each configuration was achieved by having the receptor's atomic affinity potentials for aliphatic and aromatic carbon, oxygen, nitrogen and hydrogen atoms precalculated in a three-dimensional grid with a spacing of $0.375 \AA$. A distancedependent dielectric function was used in the computation of electrostatic interactions. 
Conflicts of Interest: The authors declare that they have no competing interests.

Author contributions: M-J.P.P. and E-M.P. designed the ligands. O.B. and M.G. performed the chemical synthesis supervised by M-J.P.P. and M-J.C. J.E.-G. performed the binding affinity assays supervised by J.F.D. S.M. performed the biological assays supervised by S.L. MJ.P.P., S.L. and E-M.P wrote the manuscript.

Acknowledgments: This project has been supported by the Spanish Ministerio de Economía y Competitividad (SAF2015-64629-C2-1-R to EMP, MJPP. and MJC) and BFU2016-75319-R (AEI/FEDER, UE) (JFD.) The authors acknowledge networking contribution by COST action CM1407 "Challenging synthesis inspired by nature - from natural products chemistry to drug discovery" (to MJPP, SL, and JFD). JFD. is a member of the CIB Intramural Program "Molecular Machines for Better Life"' (MACBET). We acknowledge Lizette Van Berckelaer, Eef Meyen and Sam Noppen for excellent technical assistance. We thank ganadería Fernando Díaz for calf brains for tubulin purification.

\section{Appendix A. Supplementary data}

Supplementary data related to this article can be found at

\section{References}

[1] G.J. Brouhard, L.M. Rice, Microtubule dynamics: an interplay of biochemistry and mechanics, Nat. Rev. Mol. Cell. Biol. 19 (2018) 451-463. https://doi.org/10.1038/s41580-0180009-y

[2] C. Dumontet, M.A. Jordan, Microtubule-binding agents: a dynamic field of cancer therapeutics, Nat. Rev. Drug Discovery 9 (2010) 790-803. https://doi.org/10.1038/nrd3253

[3] R. Kaur, G. Kaur, R.K. Gill, R. Soni, J. Bariwal, Recent developments in tubulin polymerization inhibitors: An overview, Eur. J. Med. Chem. 87 (2014) 89-124. https://doi.org/10.1016/j.ejmech.2014.09.051

[4] R.A. Stanton, K.M. Gernert, J.H. Nettles, R. Aneja, Drugs that target dynamic microtubules: a new molecular perspective, Med. Res. Rev. 31 (2011) 443-481. https://doi.org/10.1002/med20242

[5] Y. Zhao, X. Mu, G. Du, Microtubule-stabilizing agents: New drug discovery and cancer

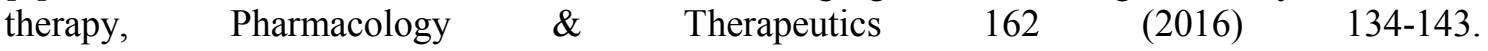
https://doi.org/10.1016/j.pharmthera.2015.12.006

[6] M.O. Steinmetz, A.E. Prota, Microtubule-Targeting Agents: Strategies To Hijack the Cytoskeleton, Trends in Cell Biology 28 (2018) 776-792. https://doi.org/10.1016/j.tcb.2018.05.001

[7] D. Bates, A. Eastman, Microtubule destabilising agents: far more than just antimitotic anticancer drugs, Br. J. Clin. Pharmacol. 83 (2017) 255-268. https://doi.org/10.1111/bcp.13126

[8] L.M. Greene, M.J. Meegan, D.M. Zisterer, Combretastatins: more than just vascular targeting agents?, J. Pharmacol. Exp. Ther. 355 (2015) 212-227. https://doi.org/10.1124/jpet.115.226225

[9] P. Mabeta, M.S. Pepper, A comparative study on the anti-angiogenic effects of DNAdamaging and cytoskeletal-disrupting agents, Angiogenesis 12 (2009) 81-90. https://doi.org/10.1007/s10456-009-9134-8 
[10] D.W. Siemann, M.R. Horsman, Modulation of the tumor vasculature and oxygenation to improve therapy, Pharmacol. Ther. $153 \quad$ (2015) 107-124. https://doi.org/10.1016/j.pharmthera.2015.06.006

[11] C. Kanthou, G.M. Tozer, Microtubule depolymerizing vascular disrupting agents: novel therapeutic agents for oncology and other pathologies, Int. J. Exp. Path. 90 (2009) 284-294. https://doi.org/10.1111/j.1365-2613.2009.00651.x

[12] M.J. Pérez-Pérez, E.M. Priego, O. Bueno, M.S. Martins, M.D. Canela, S. Liekens, Blocking blood flow to solid tumors by destabilizing tubulin: an approach to targeting tumor growth, J. Med. Chem. 59 (2016) 8685-8711. https://doi.org/10.1021/acs.jmedchem.6b00463

[13] Y.T. Ji, Y.N. Liu, Z.P. Liu, Tubulin colchicine binding site inhibitors as vascular disrupting agents in clinical developments, Curr. Med. Chem. 22 (2015) 1348-1360. https://doi.org/10.2174/0929867322666150114163732

[14] R.B.G. Ravelli, B. Gigant, P.A. Curmi, I. Jourdain, S. Lachkar, A. Sobel, M. Knossow, Insight into tubulin regulation from a complex with colchicine and a stathmin-like domain, Nature 428 (2004) 198-202. https://doi.org/10.1038/nature02393

[15] A. Massarotti, A. Coluccia, R. Silvestri, G. Sorba, A. Brancale, The tubulin colchicine domain: a molecular modeling perspective, ChemMedChem 7 (2012) 33-42. https://doi.org/10.1002/cmdc.201100361

[16] O. Bueno, J. Estévez Gallego, S. Martins, A.E. Prota, F. Gago, A. Gómez-SanJuan, M.-J. Camarasa, I. Barasoain, M.O. Steinmetz, J.F. Díaz, M.-J. Pérez-Pérez, S. Liekens, E.-M. Priego, High-affinity ligands of the colchicine domain in tubulin based on a structure-guided design, Scientific Reports 8 (2018) 4242. https://doi.org/10.1038/s41598-018-22382-x

[17] A. Cortés-Cabrera, F. Gago, A. Morreale, A computational fragment-based de novo design protocol guided by ligand efficiency indices (LEI), Methods in molecular biology (Clifton, N.J.) 1289 (2015) 89-100.

[18] F. Gago, Avaliable at http://farmamol.uah.es

[19] J. Hwang, P. Li, W.R. Carroll, M.D. Smith, P.J. Pellechia, K.D. Shimizu, Additivity of substituent effects in aromatic stacking interactions, J. Am. Chem. Soc. 136 (2014) 1406014067. https://doi.org/10.1021/ja504378p

[20] T. Tomasic, N. Zidar, R. Sink, A. Kovac, D. Blanot, C. Contreras-Martel, A. Dessen, M. Muller-Premru, A. Zega, S. Gobec, D. Kikelj, L. Peterlin Masic, Structure-based design of a new series of D-glutamic acid based inhibitors of bacterial UDP-N-acetylmuramoyl-Lalanine:D-glutamate Ligase (MurD), J. Med. Chem. 54 (2011) 4600-4610. https://doi.org/10.1021/jm2002525

[21] A. Vigroux, M. Bergon, C. Zedde, Cyclization-Activated Prodrugs: N-(Substituted 2hydroxyphenyl and 2-hydroxypropyl)carbamates based on ring-opened derivatives of active benzoxazolones and oxazolidinones as mutual prodrugs of acetaminophen, J. Med. Chem. 38 (1995) 3983-3994. https://doi.org/10.1021/jm00020a012

[22] K.S. Lim, H. Lee, S.E. Kim, T.H. Ha, J. Ann, K. Son, S. Choi, W. Sun, L.V. Pearce, I.A. De Andrea-Lazarus, P.M. Blumberg, J. Lee, The carbonate analogues of 5'-halogenated resiniferatoxin as TRPV1 ligands, Eur. J. Med. Chem. 68 (2013) 233-243. https://doi.org/10.1016/j.ejmech.2013.07.042

[23] M.D. Canela, M.J. Pérez-Pérez, S. Noppen, G. Saez-Calvo, J.F. Diaz, M.J. Camarasa, S. Liekens, E.M. Priego, Novel colchicine-site binders with a cyclohexanedione scaffold identified through a ligand-based virtual screening approach, J. Med. Chem. 57 (2014) 3924-3938. https://doi.org/10.1021/jm401939g

[24] M.D. Canela, O. Bueno, S. Noppen, G. Saez Calvo, J. Estevez Gallego, J.F. Diaz, M.J. Camarasa, S. Liekens, M.J. Pérez-Pérez, E.M. Priego, Targeting the colchicine site in tubulin through cyclohexanedione derivatives, RSC Adv. 6 (2016) 19492-19506. https://doi.org/10.1039/C5RA26807A

[25] D. Leynadie, V. Peyrot, M. Sarrazin, C. Briand, J.M. Andreu, G.A. Rener, C. Temple, Tubulin binding of two 1-deaza-7,8-dihydropteridines with different biological properties: enantiomers NSC 613862 (S)-(-) and NSC 613863 (R)-(+), Biochemistry 32 (1993) 1067510682. https://doi.org/10.1021/bi00091a018 
[26] J.F. Diaz, J.M. Andreu, Kinetics of dissociation of the tubulin-colchicine complex Complete reaction scheme and comparison to thermodynamic measurements, J. Biol. Chem. 266 (1991) 2890-2896.

[27] F. Cortese, B. Bhattacharyya, J. Wolff, Podophyllotoxin as a probe for colchicine bindingsite of tubulin., J. Biol. Chem. 252 (1977) 1134-1140.

[28] L.F. Tietze, T. Hungerland, A. Duefert, I. Objartel, D. Stalke, Synthesis of tetrasubstituted alkenes through a palladium-catalyzed domino carbopalladation/C-H-activation reaction, Chem. Eur. J. 18 (2012) 3286-3291. https://doi.org/10.1002/chem.201103209

[29] J.D.C. Mole, E.E. Turner, Intramolecular substitution as a means of comparing activating and deactivating effects, J. Chem. Soc. (1939) 1720-1724. https://doi.org/10.1039/jr9390001720 [30] M. Huang, L. Wang, X. Li, S. Yan, K.W.K. Yeung, P.K. Chu, Z. Xu, C. Yi, Design and preparation of novel fluorescent polyimides containing ortho-linked units and pyridine moieties, Des. Monomers Polym. 15 (2012) 389-404. https://doi.org/10.1080/1385772X.2012.686691

[31] Z. Chen, Y. Wu, Y. Liu, S. Yang, Y. Chen, L. Lai, Discovery of dual target inhibitors against cyclooxygenases and leukotriene A4 hydrolase, J. Med. Chem. 54 (2011) 3650-3660. https://doi.org/10.1021/jm200063s

[32] C. Yang, S. Chen, M. Zhou, Y. Li, Y. Li, Z. Zhang, Z. Liu, Q. Ba, J. Li, H. Wang, X. Yang, D. Ma, R. Wang, Development of 3-Phenyl-N-(2-(3-phenylureido)ethyl)-thiophene-2sulfonamide Compounds as Inhibitors of Antiapoptotic Bcl-2 Family Proteins, ChemMedChem 9 (2014) 1436-1452. https://doi.org/10.1002/cmdc.201400058

[33] S. Liekens, S. Gijsbers, E. Vanstreels, D. Daelemans, E. De Clercq, S. Hatse, The nucleotide analog cidofovir suppresses basic fibroblast growth factor (FGF2) expression and signaling and induces apoptosis in FGF2-overexpressing endothelial cells, Mol. Pharmacol. 71 (2007) 695-703. https://doi.org/10.1124/mol.106.026559

[34] J.M. Andreu, Tubulin purification, in: J. Zhou (Ed.) Methods in Molecular Medicine, Humana Press Inc, Totowa. NJ, 2007, pp. 17-28.

[35] C. Temple, G.A. Rener, R.N. Comber, New anticancer agents - Alterations of the carbamate group of ethyl (5-amino-1,2-dihydro-3-phenylpyrido-3,4- $b$-pyrazin-7-yl)carbamates, J. Med. Chem. 32 (1989) 2363-2367. https://doi.org/10.1021/jm00130a023

[36] M. Allan, S. Manku, E. Therrien, N. Nguyen, S. Styhler, M.-F. Robert, A.-C. Goulet, A.J. Petschner, G. Rahil, M.A. Robert, R. Deziel, J.M. Besterman, H. Nguyen, A. Wahhab, NBenzyl-1-heteroaryl-3-(trifluoromethyl)-1H-pyrazole-5-carboxamides as inhibitors of coactivator associated arginine methyltransferase 1 (CARM1), Bioorg. Med. Chem. Lett. 19 (2009) 1218-1223. https://doi.org/10.1016/j.bmcl.2008.12.075

[37] J.F. Diaz, R.M. Buey, Characterizing Ligand-Microtubule binding by Competition Methods, in: J. Zhou (Ed.) Methods in Molecular Medicine, Humana Press Inc., Totowa, NJ, 2007, pp. 245-260.

[38] P.J. Goodford, A computational procedure for determining energetically favorable binding sites on biologically important macromolecules, J. Med. Chem. 28 (1985) 849-857. https://doi.org/10.1021/jm00145a002

[39] D.N.A. Boobbyer, P.J. Goodford, P.M. McWhinnie, R.C. Wade, New hydrogen-bond potentials for use in determining energetically favorable binding-sites on molecules of known structure, J. Med. Chem. 32 (1989) 1083-1094. https://doi.org/10.1021/jm00125a025

[40] G.M. Morris, R. Huey, W. Lindstrom, M.F. Sanner, R.K. Belew, D.S. Goodsell, A.J. Olson, AutoDock4 and AutoDockTools4: Automated docking with selective receptor flexibility, J Comput Chem 30 (2009) 2785-2791. https://doi.org/10.1002/jcc.21256 